\title{
Burden-sharing \\ Multi-level Governance: A Study of the \\ CONTACT M゙ GROUP \\ ON PIRACY OFF THE COAST OF SOMALIA
}

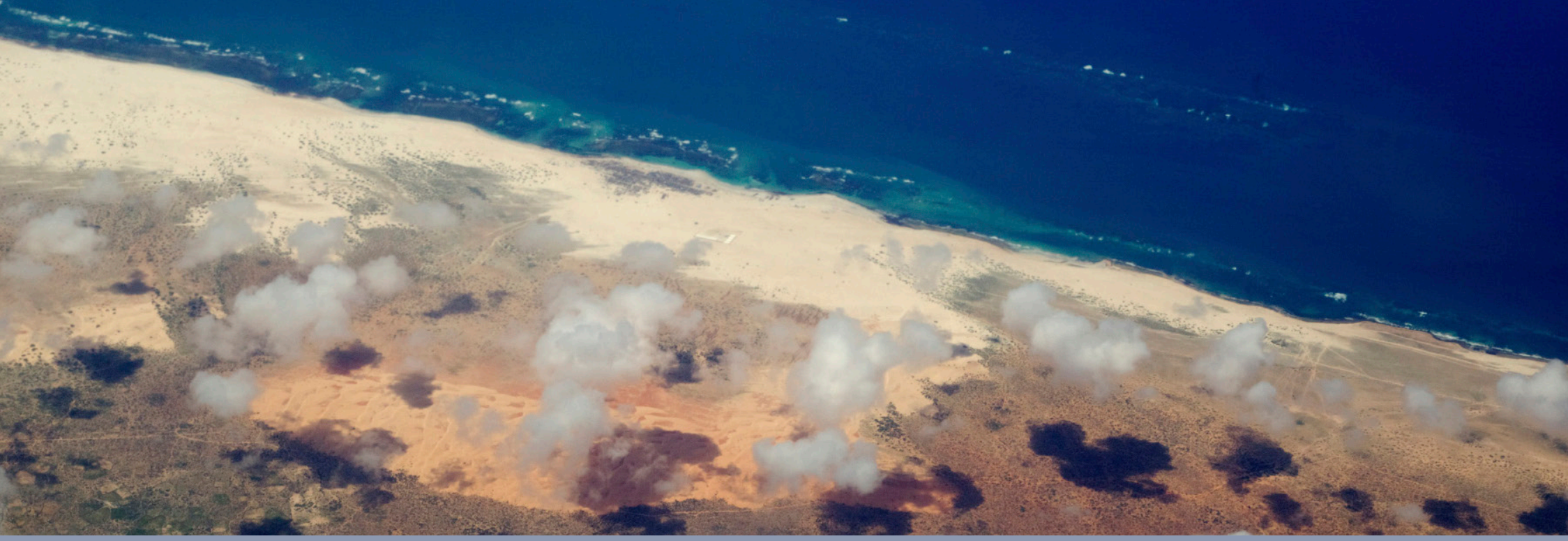

A One Earith Future and Oceans Beyond Piracy Report by

Danielle A. Zach, D. Conor Seyle, and Jens Vestergaard Madsen 
COVER PHOTO: Coastline of Somalia, near Mogadishu 


\section{Burden-Sharing Multi-LeVel GovernanCE:}

\section{A Study of the Contact Group on Piracy off the Coast of Somalia}

A One Earth Future and Oceans Beyond Piracy Report by

Danielle A. Zach, D. Conor Seyle, and Jens Vestergaard Madsen 



\section{Contents}

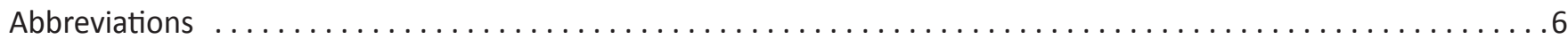

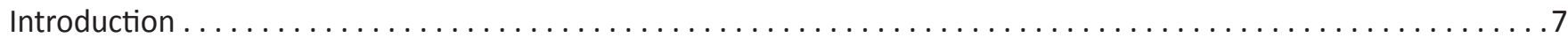

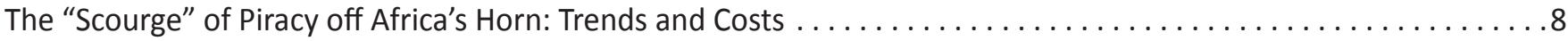

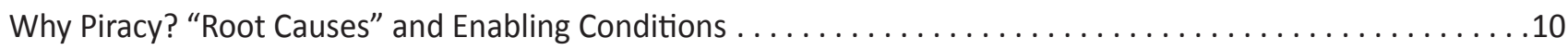

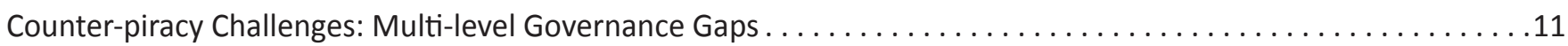

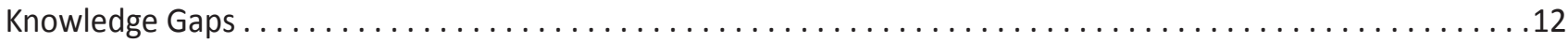

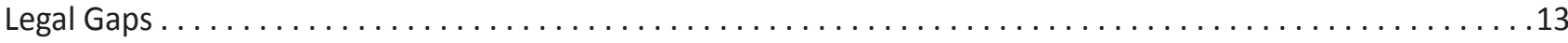

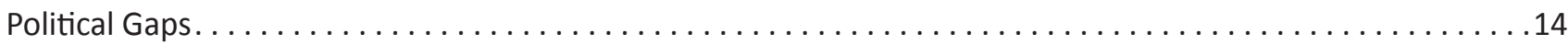

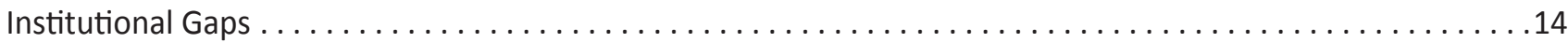

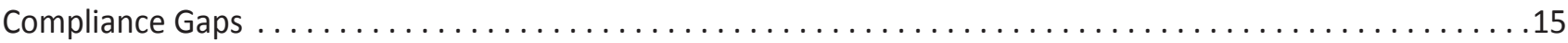

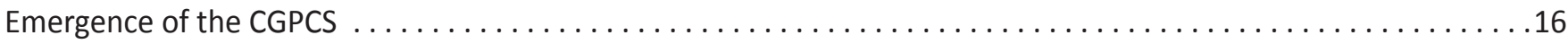

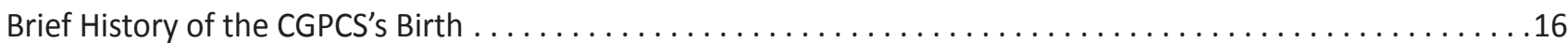

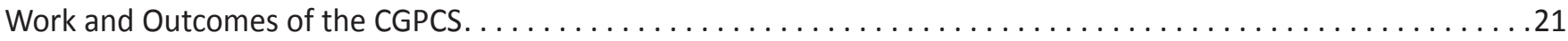

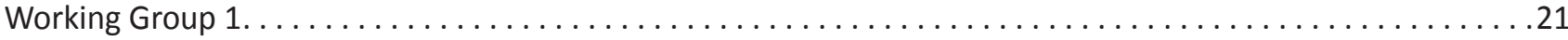

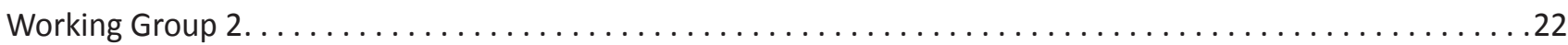

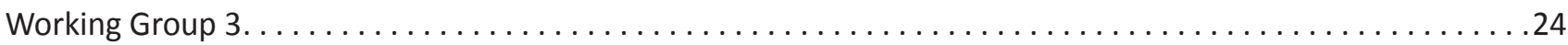

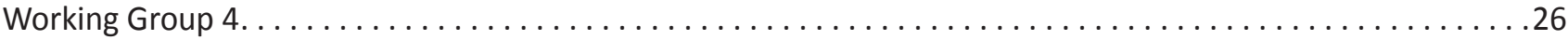

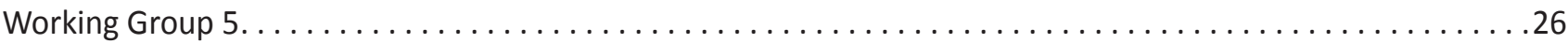

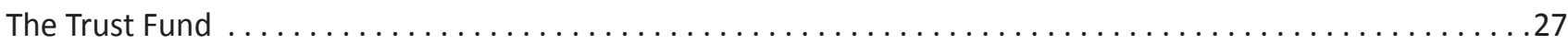

Impact of International Efforts on Filling Gaps $\ldots \ldots \ldots \ldots \ldots \ldots \ldots \ldots \ldots \ldots \ldots \ldots \ldots \ldots \ldots \ldots \ldots \ldots \ldots \ldots \ldots \ldots \ldots \ldots \ldots \ldots .27$

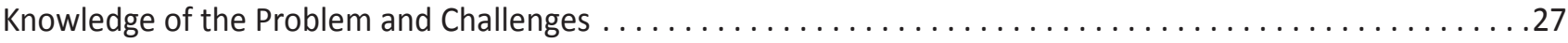

Legal Developments at the International and Domestic Levels . . . . . . . . . . . . . . . . . . . 29

Generating Political Will to End Impunity. . . . . . . . . . . . . .

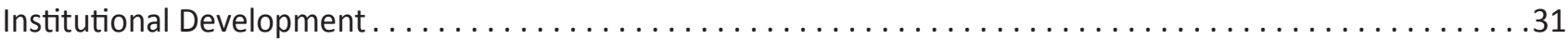

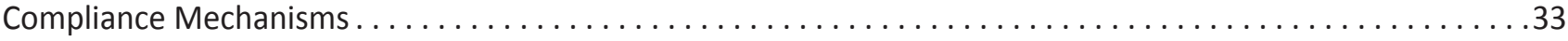

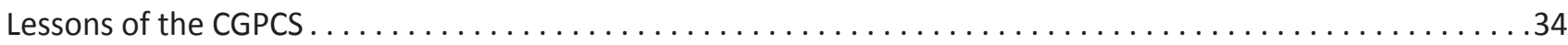

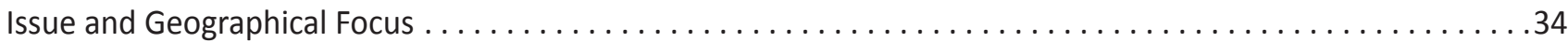

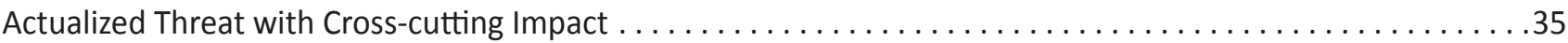

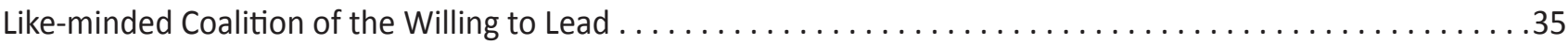

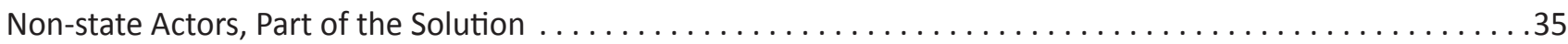

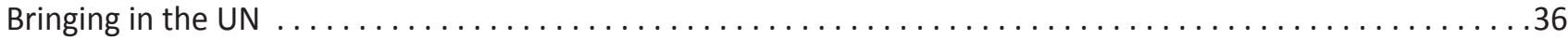

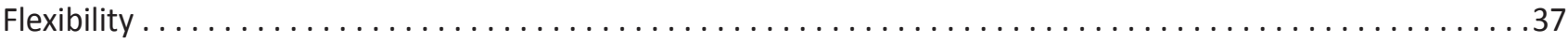

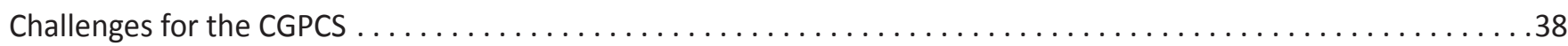

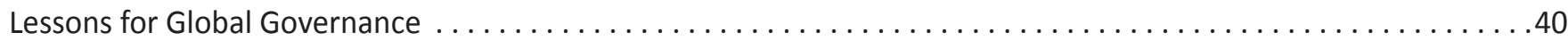

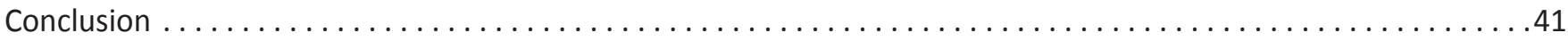

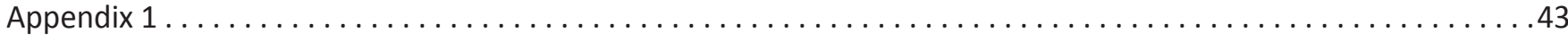

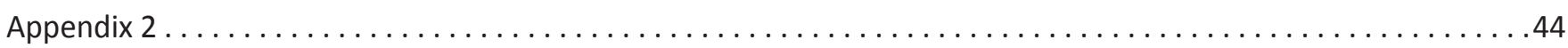

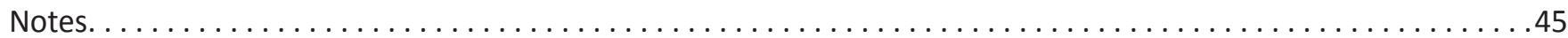

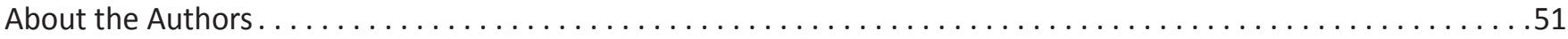




\section{Illustrations}

\section{Figures}

Figure 1: Somalia-based Pirate Attempts, Hijacks, and Hostages Taken, 2005-2012 . . . . . . . . . . . . . 8

Figure 2: Total cost of Somalia-based piracy (in billions), $2010-2012 \ldots \ldots \ldots \ldots$

Figure 3: Geographic and Temporal Distribution of Piracy Prosecutions . . . . . . . . . . . . . 30

\section{Tables}

Table 1: Somalia-based Hostages Captured, Injured, and Killed, 2005-2012 . . . . . . . . . . . . . . . . . 9

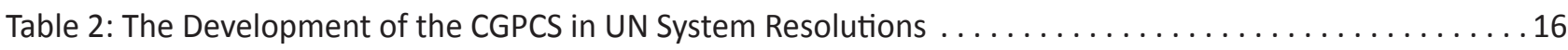




\section{Abbreviations}

\begin{tabular}{|c|c|}
\hline AMISOM & African Union Mission in Somalia \\
\hline CGPCS & Contact Group on Piracy off the Coast of Somalia \\
\hline CTF & Combined Task Force \\
\hline EU NAVFOR & European Union Naval Force \\
\hline ICS & International Chamber of Shipping \\
\hline IGO & intergovernmental organizations \\
\hline $\mathrm{IMB}$ & International Maritime Bureau \\
\hline IMO & International Maritime Organization \\
\hline INTERPOL & International Criminal Police Organization \\
\hline MARAD & Maritime Administration (United States) \\
\hline MARLO & Maritime Liaison Office (United States) \\
\hline MSC-HOA & Maritime Security Centre - Horn of Africa \\
\hline NATO & North Atlantic Treaty Organization \\
\hline NGO & nongovernmental organization \\
\hline OBP & Oceans Beyond Piracy \\
\hline ROK & Republic of Korea \\
\hline SHADE & Shared Awareness and Deconfliction \\
\hline SUA & $\begin{array}{l}\text { Convention on the Suppression of Unlawful Acts Against the Safety of } \\
\text { Maritime Navigation }\end{array}$ \\
\hline TFG & Transitional Federal Government (Somalia) \\
\hline UAE & United Arab Emirates \\
\hline UKMTO & United Kingdom Maritime Trade Operations \\
\hline UNCLOS & United Nations Convention on the Law of the Sea \\
\hline UNDP & United Nations Development Programme \\
\hline UNDPA & United Nations Department for Political Affairs \\
\hline UNODC & United Nations Office on Drugs and Crime \\
\hline UNOLA & United Nations Office of Legal Affairs \\
\hline UNPOS & United Nations Political Office on Somalia \\
\hline WFP & World Food Programme \\
\hline
\end{tabular}





\section{Introduction}

The world confronts many threats with transnational dimensions that transcend the capacity of states, individually or collectively, to address. While the United Nations and other intergovernmental organizations (IGOs) can mitigate obstacles to international cooperation, such institutions at present are unable to fill governance gaps at the global level, as they are oftentimes under-resourced by their member states, lack compliance mechanisms, and are procedurally hidebound. Today's challenges require novel approaches that include diverse stakeholders. The subject of this study is one such initiative: the Contact Group on Piracy off the Coast of Somalia (CGPCS), which emerged with a UN Security Council imprimatur in January 2009. ${ }^{1}$ The CGPCS is a voluntary mechanism for states to collectively address maritime piracy emanating from Somalia as a threat to regional stability, trade, and energy security and has increasingly embraced nongovernmental actors as necessary partners. The aim of this paper is twofold: first, to analyze the contact group's historical development, its efforts to fill governance gaps in the anti-piracy regime, and the challenges it faces; and second to evaluate the CGPCS's utility as a model mechanism for solving complex transnational problems. It seeks to engage policy and academic specialists concerned with maritime crime and global governance more broadly.

This study begins with a brief examination of the contemporary development of piracy and armed robbery at sea in the Horn of Africa. This review details trends in their occurrence and success as well as their economic and human costs. It then analyzes governance gaps as they relate to these maritime crimes. It subsequently examines the international community's response to what governments have called a "scourge" in the Gulf of Aden and Western Indian Ocean, documenting the CGPCS's historical development, dissecting its institutional configuration and output, and assessing the effectiveness of its efforts on land and at sea to suppress piracy off Somalia's coast. It concludes with a critical analysis of the value of this mechanism as a model global governance initiative.

The study finds that the CGPCS has indeed fostered the emergence of an anti-piracy community. Given that piracy is a cross-cutting issue area involving multiple ministries/departments within governments (e.g., defense, transportation, foreign affairs, finance), the contact group has cultivated horizontal linkages among national bureaucracies. The mechanism has also fostered the development of counter-piracy institutions in various countries and in international organizations, including UN agencies.

The CGPCS is most remarkable for its flexibility and inclusiveness of a broad range of states, relevant IGOs, and private industry actors. While somewhat constrained by diplomatic norms and processes, the group's informal structure has allowed it to adapt its working methods, extend participation to non-state actors, and circumvent procedural constraints that can hamstring creativity and efficiency in finding solutions to problems. The trade-off, however, is limited visibility and inclusiveness in agenda-setting and decision-making processes. The CGPCS is almost as state-centric as its counterpart UN and regional organizations-undeniably power lies with states, and particularly the most resourced among them.

This analysis suggests that the CGPCS will be a useful model for collective efforts that address problems requiring fast and adaptive responses to changing situations on the ground, and on issues where power imbalances between actors will not scuttle the collaborative execution of collective goals. However, the CGPCS's applicability as a model for other issue areas is limited by the scope conditions that allow for its effectiveness: a convergence of state interests-particularly among powerful states, some of whom are unlikely bedfellows-to suppress the problem; a coalition of the willing able to bear costs; and a very circumscribed geographic area of concern. One broad lesson that can be garnered from the CGPCS is that large global governance dilemmas are perhaps best addressed in small pieces. Another lesson is that problem solving can be more effective when state and non-state actors are encouraged to assume responsibility for tasks in which they have a comparative advantage. 


\section{The "Scourge" of Piracy off Africa's Horn: Trends and Costs}

The nearly unchecked growth of piracy in the Gulf of Aden and Western Indian Ocean during the first decade of the twenty-first century generated significant concerns from the commercial shipping industry and among states within the region and beyond. In 2009, the CGPCS was formed to suppress piracy off of Somalia's coast. This section provides a brief historical review of this "scourge" and its associated economic and human costs.

In the early 2000s, incidents of piracy attacks surged dramatically, increasing five-fold over the course of 2008 alone. According to the International Chamber of Commerce's International Maritime Bureau (IMB), there were 293 attacks in total, 49 ships hijacked, and 889 hostages in that year. ${ }^{2} \mathrm{~A}$ large part of this increase was concentrated off the coast of Somalia, a country that for two decades had lacked a functioning central government. In 2008, UN Security Council resolution 1816 formally stated that piracy was exacerbating "the situation in Somalia which continues to constitute a threat to international peace and security in the region." ${ }^{3}$ The following year Somali pirates were responsible for over half, or 218, of the 406 incidents of piracy and armed robbery at sea that occurred worldwide. ${ }^{4}$ The maritime industry did not fare much better in 2010, with 219 successful or attempted attacks and more than 1,000 seafarers held hostage, ${ }^{5}$ leading the New York Times East Africa correspondent to exclaim, "The Pirates are Winning!"6

\section{FIGURE 1: Somalia-based Attempts, Hijacks, \& Hostages Taken 2005-20127}

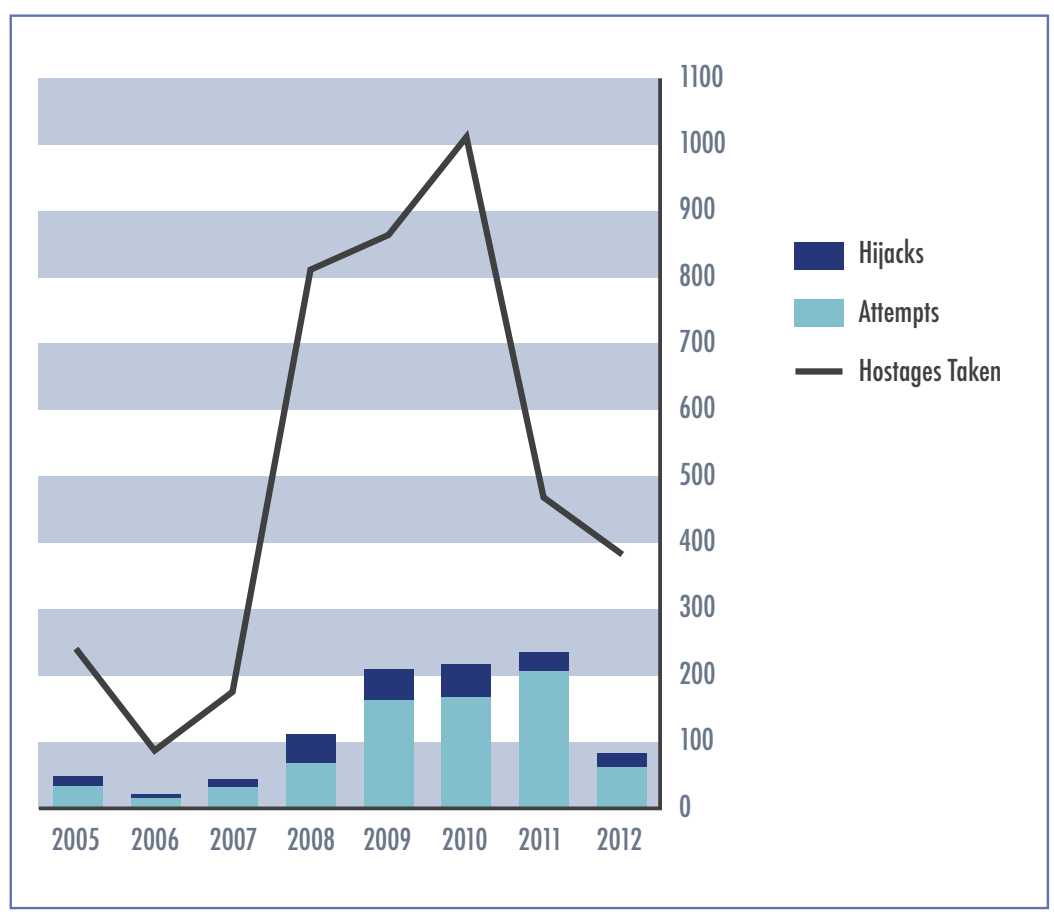

Alongside this surge, the economic and social impact of piracy began to climb. Somali piracy is predicated on the capture and ransom of a ship and crew as a package, a model that has allowed pirates to command enormous sums of money. These sums sharply increased as piracy developed. The average ransom in 2005 was $\$ 150,000 ;{ }^{8}$ by 2011 , this figure had risen to $\$ 5$ million. ${ }^{9}$ According to the UK-led International Piracy Ransoms Task force, between 2008 and 2012 an estimated $\$ 300$ million in total had been paid to Somali pirates.$^{10}$ To put this into perspective, these payments are almost twice the combined amount of humanitarian assistance and development aid that Somalia received during this period. ${ }^{11}$ Ransoms are just one piece of the global economic 
impact. An assessment by the One Earth Future Foundation's Oceans Beyond Piracy (OBP) project estimated that the costs of Somali piracy, when all factors were considered, amounted to approximately $\$ 6$ billion in 2012, down from nearly $\$ 7$ billion in 2011 and an estimated \$7-12 billion in 2010. ${ }^{12}$ Figure 2 shows the total cost of Somalia-based piracy from 2010-2012.

\section{FIGURE 2: Totall Cost of Somalia-based Piracy (In Billions) 2010-2012 ${ }^{13}$}

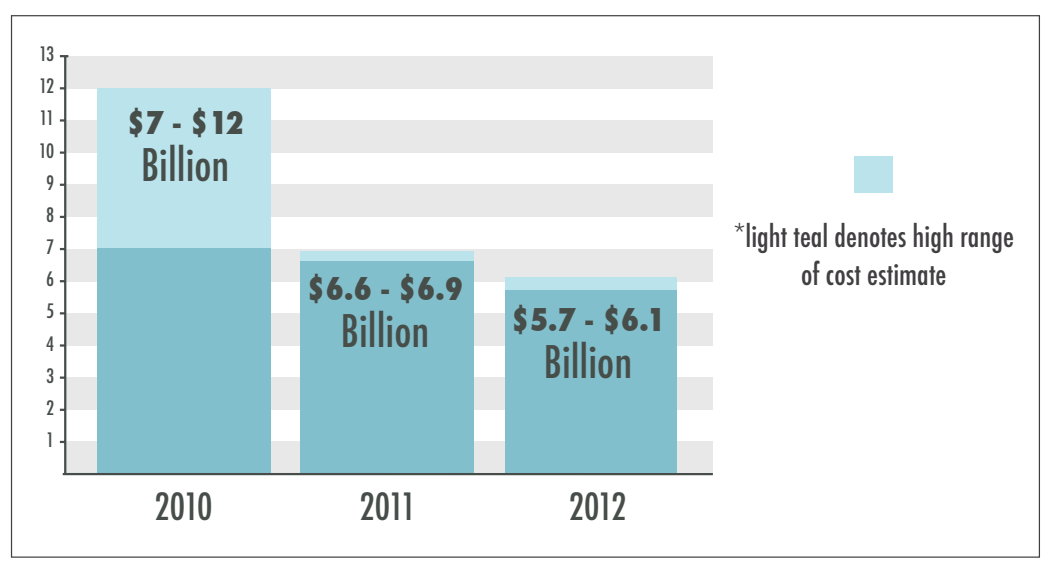

In addition to the economic costs, piracy has also exacted significant human costs. The numbers of victims are sobering. In 2011, 3,863 seafarers were aboard ships that were fired upon by pirates. Nearly 970 seafarers were aboard ships that were boarded by armed pirate gangs. That year, 470 new hostages joined the 645 who had already been captured, while eight died in captivity. ${ }^{14}$ Moreover, the average length of captivity for hostages is five months and some have been held for almost three years. ${ }^{15}$ Beyond the individual seafarers, these incidents brought anguish to family members and whole communities. Table 1 shows the numbers of hostages taken, injured, and killed since 2005. This impact fell disproportionately on seafarers from the developing world: 93 percent of all hostages were from non-OECD (Organisation for Economic Co-operation and Development) countries, with the largest numbers from the Philippines (17 percent), China (9 percent), and India ( 8 percent). ${ }^{16}$

\section{Table 1: Somalia-based Hostages Captured, Injured, and Killed, 2005-201217}

\begin{tabular}{|l|l|l|l|}
\hline Year & $\begin{array}{l}\text { Hostages } \\
\text { Taken }\end{array}$ & $\begin{array}{l}\text { Hostages } \\
\text { Injured }\end{array}$ & $\begin{array}{l}\text { Hostages } \\
\text { Killed }\end{array}$ \\
\hline 2005 & 241 & 1 & 0 \\
\hline 2006 & 87 & 2 & 1 \\
\hline 2007 & 177 & 6 & 2 \\
\hline 2008 & 815 & 2 & 4 \\
\hline 2009 & 867 & 10 & 4 \\
\hline 2010 & 1,016 & 13 & 8 \\
\hline 2011 & 470 & 3 & 8 \\
\hline 2012 & 250 & 1 & 2 \\
\hline TOTALS & 3,923 & 38 & 29 \\
\hline
\end{tabular}


Why Piracy? "Root Causes" and Enabling Conditions

As piracy exploded and exacted significant economic and human costs on a diverse array of actors, businesses and affected states began to develop a variety of counter-piracy strategies and activities. These necessarily engaged the question of why Somali piracy had developed, which has typically been approached from two angles: the "root causes" of piracy, entailing assumptions about individual motives; and enabling conditions. Piracy can be analyzed from either starting point.

Regarding the first approach, two hypotheses have been advanced about so-called root causes: greed and grievance. In cautioning the use of the very term "root causes," US counter-piracy and maritime security coordinator Donna Hopkins emphatically asserts that the "root cause of piracy off the coast of Somalia is human greed; it is not poverty ... [but rather] the willingness of some ... to victimize others for their own personal gain. Saying that poverty 'causes' piracy seriously disrespects the millions of honorable Somalis whose own poverty has not led them to engage in extortion, kidnapping, and murder of innocent seafarers." ${ }^{\prime 18}$ The greed motivation is obvious: weapons and boats in Somalia are easily accessible, so the initial costs are relatively low while, as noted above, the pay-off is potentially staggering for investors and pirates alike.

It is unsurprising that pirate organizers have not been lacking for recruits given the dire economic context of Somalia, a country that ranked fifth from the bottom on the UNDP's Human Development Index (HDI) in $2010 .{ }^{19}$ Although the kingpins of piracy are well-connected elites within Somalia and abroad, ${ }^{20}$ the UNDP's 2012 report speculates that foot-soldiers are mostly unemployed males. The UNODC estimates that one ransom payment is potentially the equivalent of a salary earned in two to three years as an employee of an international humanitarian agency, and these agencies generally provide much higher wages than local sources of employment. ${ }^{21}$ According to a 2013 World Bank report, the prevailing earnings for unskilled/low-skilled labor are $\$ 859 /$ year, which pale in comparison to a payout of $\$ 10,500$ for a successful attack or even the $\$ 400 /$ month average wage an armed guard aboard a hijacked ship can earn. ${ }^{22}$

The grievance narrative adopted by pirates and armed robbers to justify crime is based on perceptions of exploitation. They have claimed that illegal fishing vessels as well as illegal toxic dumping in Somali waters were damaging livelihoods and prompted local fishermen to "police" the coast and extract "taxes" from foreign vessels. It is not only pirates who have couched piracy within this injustice framing: the prime minister of Somalia's transitional government, Abdiweli Mohamed Ali, for example, publicly blamed poaching by international trawlers in Somali waters as pushing local fishermen to undertake desperate measures. ${ }^{23}$

Which of these explanations is the "root cause" remains contentious. The UN Monitoring Group on Somalia and Eritrea has asserted that "exploitation of Somali marine resources is a reality, but it is by no means a preoccupation of Somali pirates or their backers." ${ }^{24}$ Similarly, as Stig Hansen's analysis of the targets of pirate attacks from 1998-2008 found, the most frequent target of pirate attacks were "generally not trawlers fishing illegally but ordinary cargo ships and bulk carriers just passing through Somali, Yemeni or international waters." 25 The activities of pirates would suggest that their motives are more economic than protective, but the coastguarding rationale may provide an important way for pirates to gain local support.

The second approach to analyzing piracy trends emphasizes the collapse of local institutions within Somalia. A crucial function of a state is to provide internal order with its borders. Yet since the fall of Said Barre's dictatorship in 1991, Somalia has experienced the near complete uncoupling of centralized coercive authority and territorial jurisdiction. In the 2000s, many areas within Somalia lacked any form of local policing or judicial institutions, allowing pirates to operate with impunity. With few restraints imposed by a central state or even local institutions, legal risk was virtually nonexistent. During the Supreme Council of Islamic Courts' (SCIC) brief 
rule, which banned piracy as against Islam in 2006, piracy effectively collapsed. Yet after the repressive SCIC was ousted, piracy rebounded and became more virulent than before. ${ }^{26}$

The capture and ransom of ships and their crews are possible in part because of the government's lack of control over its own ports and coastal areas. Maritime criminals in Somalia can operate without having to be concerned with government policing-a luxury that few other pirates have elsewhere around the globe. ${ }^{27}$ At the same time, Somalia suffers from endemic corruption. According to the watchdog, Transparency International, Somalia ranks at the very bottom of its 2012 corruption index alongside North Korea and Afghanistan. This has meant that some authorities in the fragmented country profit from piracy, thereby aiding and abetting maritime crime from Somali shores. In early 2009, UN Secretary-General Ban Ki-moon noted to the Security Council reports of "complicity" by authorities in piracy activities. ${ }^{28} \mathrm{~A} 2013$ World Bank report further argued that pirates need tacit support from key local leaders in order to maintain moored vessels offshore and conduct lengthy ransom negotiations. ${ }^{29}$ Hence, weak state capacity and rule of law create conditions within which maritime crime can thrive.

These explanations of trends have underpinned counter-piracy initiatives-which have included the deployment of naval forces to the region; self-protection measures for ships transiting high-risk areas; regional judicial capacity development; and messaging to discourage local support within Somalia. Before fleshing out the details of these efforts, it is important to note that the pre-2009 global response was piecemeal and uncoordinatednot uncommon problems in global governance generally. The next section therefore situates piracy within a larger theoretical framework developed to assess "governance gaps."

\section{Counter-piracy Challenges: Multi-level Governance Gaps}

As piracy surged, a variety of stakeholders sought to actively suppress the growing threat to their national and commercial interests. These diverse actors, however, held different views on the problem's scope and causes and how best to approach it, leading to a hodgepodge of uncoordinated responses that were incomplete and potentially overlapping and contradictory. Collective action is an inherent dilemma in a world system that lacks supranational authority. To borrow a metaphor from Kishore Mahbubani, the current international system is akin to a listing boat with "193 captains and crews, each claiming exclusive responsibility for one cabin. However, it has no captain or crew to take care of the boat as a whole." ${ }^{30}$ This reality presents substantial challenges for cooperation in a world with increasingly common threats that require robust and timely responses. Piracy in the East African context, however, is not only an issue of collective responsibility for the global commons-for the metaphorical boat as a whole-as are some other overarching issues such as climate change, for example. It has become one, but it is also another symptom of inadequately governed territorial space that falls within the recognized jurisdiction of a fragmented government.

In the case of piracy, burden-sharing governance at the problem's source and affected areas of the high seas is necessary to at least suppress it. Yet domestic governance problems that spill over into the global commons must be solved within the existing normative framework underpinning world order-state sovereignty and its corollary principle of noninterference. The task for those seeking to eradicate maritime crime emanating from these "high-risk" areas is twofold: generating political will and active participation from private-sector stakeholders to solve the problem collectively (i.e., overcoming the "free rider" problem); and skillfully navigating potential constraints imposed by state sovereignty, while building state capacity in the long term. At the same time, state actors must also reconcile such efforts with robust international human rights norms.

Its founding member states created the GCPCS to resolve or at least ameliorate gaps in the overall response to piracy. Each of its initial four, later five working groups were tasked with addressing a specific issue area:

1. naval and capacity-building coordination and information sharing;

2. legal and judicial issues; 
3. shipping industry self-protection;

4. messaging and public information efforts, and;

5. disruption of the pirate enterprise ashore, through identifying and disrupting the financial networks of pirate leaders and their financiers

These practical issues can be situated and analyzed within general governance dilemmas identified by international relations scholars. In order to facilitate comparison between the CGPCS and other mechanisms, this section analyzes the challenges of counter-piracy through a modified application of Thomas G. Weiss and Ramesh Thakur's analytical framework of global governance gaps. It examines counter-piracy gaps in the areas of knowledge, law, political will, institutions, and compliance. ${ }^{31}$ This paper will subsequently return to these gaps to assess the extent to which the CGPCS's efforts have closed them on this issue area. In doing so the analysis aims to draw out lessons for global problem-solving initiatives.

Knowledge Gaps

A prerequisite to collective action is a shared understanding that a particular threat even exists, as well as an understanding about its characteristics, causes, and consequences. As with many other issue areas, there were significant knowledge gaps about piracy when attacks sharply increased over the first decade of the twenty-first century. Peter Hinchliffe, secretary-general of the International Chamber of Shipping (ICS), noted that while there had been low-level piracy in the region for many years, the hijacking of ships signaled the start of a new business model. The ICS faced the challenge of generating attention from the international community. As he explains, "It was becoming of such great concern . . . ICS became involved in trying to engage the interest of governments in understanding first of all there was a problem, and secondly understanding that the problem had an impact on world trade because it was going to influence the routing of ships." 32

First and foremost, fundamental information was unavailable. Despite the existence of several voluntary reporting mechanisms, such as the IMB Piracy Reporting Center, established in 1992 in Kuala Lumpur, precise and real-time figures on the very frequency and location of incidents of piracy and armed robbery at sea were hard to come by. Moreover, data on the economic impact was not widely available, as evidenced by the methodological challenges faced by OBP in its very first cost report published in 2010. The absence of basic facts made it difficult to accurately measure the magnitude of the problem, to identify patterns of violence, and thus to develop a strategy to counteract the threat.

Second, there was a lack of clarity about the very international legal framework in existence to address the problem. Indeed there was debate about the relevance of existing international conventions and treaties, some of which were premised on outdated assumptions about piracy or on other concerns such as terrorism. As Danish Ambassador Thomas Winkler noted, "In 2009. . . we had all the delegates looking at one another and asking, 'What is piracy from a legal perspective, and how do we deal with it?' And there were very few answers at the time." ${ }^{33}$

Third, there was dispute over the driving force of piracy-greed or grievance. In addition to the obvious issue of poverty, those championing the latter explanation, including some Somali officials, claimed that illegal fishing and toxic waste dumping by foreign vessels were key factors in fueling the phenomenon. Others remained unconvinced that external exploitation played any causal role, arguing that piracy was purely a greed-driven phenomenon. Despite disputes over motivations, however, there was a broad consensus that the lack of a central government in Somalia and state incapacity enabled maritime crime within the country's coastal waters and on the high seas. Yet the way forward was hardly clear.

Fourth, in addition to Somalia the capacity weaknesses among neighboring countries that were adversely affected by piracy stemming from Somali shores, such as Kenya, Seychelles, and Yemen, were yet to be 
identified. These states were implicated in the response to piracy, but little was known about their enforcement and judicial capabilities to counter growing maritime crime in and around their coastal waters.

Fifth, there was a dearth of knowledge about the financers of pirate operations and sources of weaponry and technological equipment. In this regard, perhaps the only obvious dimension to this aspect of the problem was that the Security Council's decade-and-a-half old arms embargo on Somalia was being systematically violated. ${ }^{34}$ Moreover, the actual flows of cash from ransom payments were unknown. Similarly, the linkages between maritime crime and other criminal operations such as human trafficking and smuggling remained opaque.

Legal Gaps

For centuries piracy has been seen as an enemy of humankind-hostis humani generis. Unlike other issue areas, such as human rights or environmental sustainability, there has long existed normative consensus about piracy. The relevant legal framework in place to address it, however, was complex and fragmented..$^{35}$ The key elements included the International Convention against the Taking of Hostages (1979); UN Convention of the Law of the Sea (UNCLOS, 1982); and the Convention on the Suppression of Unlawful Acts Against the Safety of Maritime Navigation (SUA,1988).

Among these, UNCLOS alone directly dealt with piracy. UNCLOS's framework only covers the high seas where the convention provides universal jurisdiction, granting any state the right to arrest and prosecute, but imposing no obligation for any to do so. As such, the convention provides no guidance on how to deal with pirates who operate and/or find safe haven in territorial waters. Moreover, the UNCLOS paragraphs dealing with piracy do not obligate any state to enact national laws to deal with piracy. As a result, a number of relevant states did not have anti-piracy laws in place that would enable them to prosecute suspected pirates, even if they had the political will to do so. Even in cases where national codes included anti-piracy laws, moreover, evidentiary standards were highly inconsistent across countries, as were laws about the treatment of suspects. UNCLOS has other shortcomings as well: it is vague about the meaning of intent to commit piracy and on the issue of incitement/conspiracy. ${ }^{36} \mathrm{Gei}$ and Petrig note that prosecution "requires the existence of a substantive criminal norm defining the prohibited conduct and threatening it with punishment. In the case of piracy, it is a controversial question whether such a norm exists." 37

SUA, by contrast, requires states to make offenses punishable and to prosecute or extradite suspects to states with a nexus to the crime. In this way, it fills some legal gaps. As two analysts explain: "SUA permits states with nexus to reach into the domestic territory of another state. It largely does not depend on the municipal laws of another state to operate." Yet there was debate about the relevance of SUA as piracy is not specifically referred to in the agreement, which is concerned largely with terrorism. Moreover, "unlike UNCLOS, SUA has not achieved the force of customary international law." ${ }^{38}$ That SUA rarely is invoked by states, they suggest, is a reflection of a privileging of territorial sovereignty above other concerns. While the "real gaps" may be largely political, there were quite a number of thorny legal issues that remained.

The legal challenges were significantly complicated by the complex structure of the maritime sector. It is not uncommon for a ship to be owned by a national of one country, crewed by nationals of a second, registered to a third state, and carrying cargo owned by nationals of a fourth. When one considers that the pirates attacking this cosmopolitan vessel may then be captured by navies from yet a fifth state, the question of which state should take responsibility for prosecution lacks an obvious answer. While UNCLOS and SUA addressed this by the declaration of universal jurisdiction in the first case and establishing the criteria for nexus in the second, the practical execution of prosecution under these circumstances is challenging. Even in cases where national codes included anti-piracy laws, moreover, evidentiary standards were highly inconsistent across countries, as were laws about the treatment of suspects. 
Political Gaps

If piracy is a crime of opportunity, then an absence of political will to suppress it is a key component of the challenge in mounting a concerted effort to inhibit it. When asked to elaborate on industry's most difficult issues, Hinchliffe categorically asserted: "The most critical factor . . . was getting governments to engage on the issue ... and I still regard that as one of the most critical issues . . governments have other things on their priority list." ${ }^{\prime 39}$

Aiming to mobilize action from governments within the region, the International Maritime Organization (IMO) launched and advocated for the Djibouti Code of Conduct, which by February 2009 had been adopted by 17 states and initially signed by 9: Djibouti, Ethiopia, Kenya, Madagascar, Maldives, Seychelles, Somalia, Tanzania, and Yemen. These regional states, along with another 11 later signatories, ${ }^{40}$ committed to investigating and prosecuting piracy, sharing information, and working with outside militaries. A trust fund was established to assist with practical implementation with Japan assuming a lead role. While a widely recognized step forward for a long-term solution, the efforts of such countries alone could not decrease piracy in the short term.

To this end assorted naval warships, as part of multinational forces and independently, had assumed protective roles for WFP (World Food Programme) and AMISOM (African Union Mission in Somalia) shipments as well as merchant ships transiting the high risk area. Despite their robust disruption and apprehension capabilities, more often than not patrolling militaries released suspected pirates, even in instances when there was ample evidence for conviction, as states were unable and/or unwilling to try and imprison them in accordance with their respective national laws. The "catch and release" policy, according to some observers, was driven by the lack of desire of countries to bear costs, including potential asylum claims that could, in turn, provide incentive for such criminal undertakings. An estimated 90 percent of all pirates captured at sea were released. ${ }^{41}$

Meanwhile, industry worked with other stakeholders to develop self-protection guidelines, known as the Best Management Practices (BMPs) to help ships avert successful attacks. However, there was little interest in endorsing international naval efforts to monitor and identify those not implementing the BMPs.

Institutional Gaps

Regarding institutions, gaps existed both at the domestic and international levels to address piracy. Somalia, as well as other states in the region such as Kenya, Seychelles, and Yemen simply lacked coastal patrol and judicial capacity to grapple with maritime crime in and around their territorial waters. In 2009, the IMO-led Djibouti Code of Conduct aimed to partially fill the gap within the region with establishment of anti-piracy information sharing centers in Kenya, Tanzania, and Yemen, as well as a training center in Djibouti. Domestic capacity-building would take time, however, while the problem of piracy called for an immediate and direct response from other states and international institutions. However, a similar lack of institutionalization existed at this level, albeit for different reasons.

Among states with strong internal capacity, many national bureaucracies were simply not prepared to confront the issue of piracy and lacked internal coordination mechanisms to effectively deal with what is a cross-cutting issue area entailing multiple agencies within governments. Denmark's Ambassador Winkler noted that within his government "most departments were thrown into the issue when it began. And there was not a sort of existing competence that we could draw from. We had to start from scratch." 42 Similarly Carl P. Salicath, senior advisor at the Norwegian Ministry of Foreign affairs, explained that piracy was part of the ministry's counterterrorism portfolio and that not much time had been devoted to the issue as it was considered a routine matter. After August 2008, he noted, "we scrambled, like many others, to decide what to do about it." ${ }^{43}$

The UN system was also not prepared to confront piracy. The existing machinery dealt with aspects of piracy but not in any comprehensive way. The IMO is the specialized agency responsible for issues pertaining to commercial 
shipping; the UN Office of Legal Affairs Division of Ocean and Affairs and the Law of the Sea (UNOLA DALOS) provides legal and technical advice regarding UNCLOS; and the UNODC, a self-described "global leader in the fight against . . . international crime," did not have a counter-piracy program when piracy first surged in the region. Given the multiple problems that piracy invoked, none of these UN bodies had a clear-cut mandate to address all the aspects of piracy. The UN's Department of Political Affairs, the parent office of the Nairobi-based UN Political Office on Somalia (UNPOS), ultimately was given the responsibility for the file, and an interagency committee was established after some disagreement with the Department of Peacekeeping Operations (UNDPKO), which sought the lead role on the basis that piracy was a security issue. ${ }^{44}$

However, when the UN Security Council requested that the secretary-general to consider the UN's role in countering piracy, Ban Ki-moon asserted in his report pursuant to resolution 1846 that: "The magnitude and complexity of the various military operations currently conducted off the coast of Somalia and in the Gulf of Aden in the fight against piracy and armed robbery at sea evidently require a lead role and coordination arrangements that go beyond the operational capacity and resources of the United Nations Secretariat." ${ }^{\prime 4}$

Various countries, as noted above, had deployed military assets in the early years of the piracy boom to temporarily police the high seas and Somali waters. However, until 2008 there existed no coordinating mechanism to make effective use of naval assets among multinational forces and independent deployers. To this end, the Bahrain-based Combined Maritime Forces (CMF) with the European Union Naval Force (EU NAVFOR) and North Atlantic Treaty Organization (NATO) took the initiative to establish the Shared Awareness and Deconfliction (SHADE) mechanism in December 2008-which began, according to one interviewee, as a few military officers sitting around a table. ${ }^{46}$

There were also a number of reporting centers to assist commercial ships: EU NAVFOR's Maritime Security Centre-Horn of Africa (MSC-HOA), the United Kingdom's Maritime Trade Operations (UKMTO), the NATO shipping center, and the US Navy's Maritime Liaison Office (MARLO), as well as the IMB. Thus there was a patchwork of military and civilian institutions interfacing with shipping, leading to issues of overlap and duplication. There were also some differences in practices of how to respond to reports of attacks from ship masters.

The glaring institutional gaps pertaining to information sharing, leadership, and coordination among relevant actors at the international level imposed serious constraints on mounting an effective response. These gaps were compounded by existing gaps in enforcing compliance.

Compliance Gaps

One of the biggest challenges of global governance revolves around the lack of compliance mechanisms to ensure that actors indeed take action to further collective goals. There is no supranational authority that can enforce compliance with maritime security standards or ensure that states implement appropriate laws in accordance with their obligations under SUA. As Scott Barrett notes, "organized volunteerism" is often the only available option to confront many global problems, including ones that require military responses. ${ }^{47}$

While the UN Security Council can act under Chapter VII of the Charter, which is binding on member states, it must beg and borrow troops and equipment from willing national governments. According to one UN official, there were debates within the Security Council about deploying naval "blue hats" to the region up until early 2012:

Who will provide naval assets? Who will support it? ...It's not just about sending blue-hatted personnel. There are very complex organizational issues ... such as naval personnel contribution from Member States, deployment of naval assets under UN command, recruitment of support staff, medical clearance, salary, rest and recuperation breaks, et cetera. Generally the UN even now faces difficulties 
getting assets; for example transport helicopters are not forthcoming, and here we are talking about very expensive naval ships. Up until late last year, there were some advocating for UN blue helmets." [In February 2012, India had called for a blue-hatted navy. By November 2012] with 40 countries debating in the Security Council, no one country called for blue-hatted peacekeepers. People realized it would be very, very expensive. Then these warships could be used by others. They realized gradually. There is no longer any demand for a blue-hatted navy. ${ }^{48}$

As noted above, the naval enforcement duties fell to national and international military forces, whose missions, timelines, and rules of engagement varied significantly. It was in this context that then US Secretary of State Condoleezza Rice noted before the UN Security Council in late 2008 that the international response at that time was less than the sum of its parts. ${ }^{49}$

\section{Emergence of the CGPCS}

Over the course of 2005 through 2008, various UN bodies generated resolutions calling for international action and cooperation on anti-piracy efforts while the UN secretary-general became engaged on the matter. At the same time, the issue of piracy had moved up on the agenda within national bureaucracies, in some countries as a result of domestic lobbying by the maritime industry to address the problem, in others as a result of concern for the interests of directly affected allies. This context meant that there was increasing national and international political interest in counter-piracy operations, appreciation of the complexity of issues relating to piracy, and acknowledgement of the need for a coordinating body to bring together all of the different actors to engage in collective problem solving. This section examines the initiatives that gave rise to the CGPCS.

\section{Brief History of the CGPCS's Birth}

During the first decade of the twenty-first century, UN bodies had become increasingly engaged in the issue of piracy and armed robbery at sea. Beginning with an IMO Assembly resolution in 2001 establishing a code of practice in investigating piracy, and culminating in 2008 with the establishment of the CGPCS pursuant to a UN Security Council resolution, the UN and associated bodies took a series of formal steps to develop and encourage effective systems to combat piracy. Table 2 shows relevant IMO, UN General Assembly, and Security Council resolutions that demarcate the development of interest and concern in the issue and the ultimate formation of the CGPCS.

\section{Table 2: The Development of the CGPCS in UN System Resolutions}

\begin{tabular}{|l|l|l|}
\hline Daffe & Evenf & Description \\
\hline November 2001 & IM0 Assembly Resolution A.922(22) & $\begin{array}{l}\text { Code of Practice for the Investigation of the Crimes of Piracy and Armed } \\
\text { Robbery Against Ships }\end{array}$ \\
\hline November 2004 & UN General Assembly Resolution 59/24 & $\begin{array}{l}\text { Urges states to cooperate with the IM0 to combat piracy and armed rob- } \\
\text { bery at sea, and to undertake capacity-building measures }\end{array}$ \\
\hline November 2005 & IM0 Assembly Resolution A.979(24) & $\begin{array}{l}\text { Urges states to implement protective measures, including by issuing } \\
\text { guidance to ships, and share information with the IM0 regarding pirate } \\
\text { incidents against vessels }\end{array}$ \\
\hline December 2006 & UN General Assembly Resolution 61/222 & $\begin{array}{l}\text { Confront maritime threats through the adoption and harmonization of } \\
\text { national laws and through the provision of enforcement vessels }\end{array}$ \\
\hline December 2007 & IMO Resolution A.1002(25) & $\begin{array}{l}\text { Calls on governments to "take all necessary judicial, legislative and law } \\
\text { enforcement action," to receive and prosecute and/or extradite suspected } \\
\text { pirates and armed robbers }\end{array}$ \\
\hline June 2008 & UN Security Council Resolution 1816 & $\begin{array}{l}\text { Authorizes naval forces off Somalia to deter and disrupt piracy, encourages } \\
\text { states to increase and coordinate efforts to counter piracy }\end{array}$ \\
\hline
\end{tabular}




\begin{tabular}{|l|l|l|}
\hline October 2008 & UN Security Council Resolution 1838 & Calls on states to suppress piracy and reaffirm UNCLOS \\
\hline December 2008 & UN Security Council Resolution 1846 & $\begin{array}{l}\text { Calls on states to criminalize piracy and to implement their obligations } \\
\text { under SUA }\end{array}$ \\
\hline December 2008 & UN Security Council Resolution 1851 & $\begin{array}{l}\text { Encourages all states and regional organizations fighting piracy and } \\
\text { armed robbery at sea off the coast of Somalia to establish an international } \\
\text { cooperation mechanism to act as a common point of contact between and } \\
\text { among states, regional and international organizations on all aspects of } \\
\text { combating piracy and armed robbery at sea off Somalia's coast }\end{array}$ \\
\hline January 14, 2009 & First CGPCS Plenary Session & Defined six focus areas and created four working groups to address them \\
\hline July 14, 2011 & Ninth CGPCS Plenary Session & $\begin{array}{l}\text { Established WG5 to focus on and coordinate efforts to disrupt the pirate } \\
\text { enterprise ashore, under the chairmanship of Italy }\end{array}$ \\
\hline
\end{tabular}

The UN General Assembly, which passed resolution 59/24 in November 2004,50 urged states to cooperate with the IMO to combat piracy and armed robbery at sea, and to undertake capacity building measures such as enforcement training. In December 2006, the assembly again called on states to act in confronting maritime threats in resolution 61/222, including through the adoption and harmonization of national laws and through the provision of naval vessels.

Among specialized agencies, it was the IMO-the UN body tasked with promoting maritime safety-that was at the forefront of sounding the international alarm on maritime crime. The organization had already began circulating counter-piracy guidelines to both governments and industry beginning in the early 1990s, ${ }^{51}$ launched an anti-piracy project in 1998, generated a code of practice for the criminal investigation of piracy and armed robbery in 2001, and also began passing resolutions urging states to take decisive action. In November 2005, IMO assembly resolution A.979 (24) strongly urged states to implement protective measures, including by issuing guidance to ships, and share information with the IMO regarding pirate incidents against vessels. It also requested its Secretary-General to transmit the resolution to the UN Secretary-General so that he could bring the matter to the attention of the UN Security Council. IMO resolution A.1002 (25) of December 2007 noted again the assembly's "grave concern" regarding incidents of piracy off the coast of Somalia, which it attributed to "a lack of lawful administration and the inability of the authorities to take affirmative action against perpetrators, which allows the 'pirate command centres' to operate without hindrance at many points along the Somali coast." 52 Drawing on the 2005 report of UN's Monitoring Group on Somalia and Eritrea to the Security Council, it further noted violations of the UN's arms embargo. In this regard, it called on governments to "take all necessary judicial, legislative and law enforcement action" to receive and prosecute and/or extradite suspected pirates and armed robbers. ${ }^{53}$

In 2007, the IMO Secretary-General sent two letters to the UN Secretary-General, briefed him on the situation, and released a joint communiqué with the WFP, which linked growing food insecurity in Somalia to piracy and armed robbery off of the country's coast. ${ }^{54}$ By the end of the year, Kofi Annan transmitted a letter to the Security Council president, which noted the TFG's desire for international assistance to combat piracy.

By June 2008, the United States and France put the issue squarely on the Security Council's agenda, which produced resolution 1816 on the issue of piracy and armed robbery off of Somalia's coast. Invoking Chapter VII of the UN Charter, the council condemned piracy, noting its role in exacerbating instability in Somalia as a threat to international peace and security, and authorized "all necessary means" to suppress it. While novel in that the resolution included armed robbery as within the scope of international jurisdiction, ${ }^{55}$ the resolution expressly affirmed Somalia's sovereignty, required permission from the TFG for states to pursue suspected pirates into Somalia's territorial waters, and explicitly stated that the authorization applied only to Somalia and that it should not be interpreted as customary law. ${ }^{56}$ The inclusion of that caveat was to palliate objections from Indonesia, which also struggled with piracy in its archipelago, about the authorization of international action within a country's domestic jurisdiction." ${ }^{17}$ 
The resolution was quickly followed by four more that year: 1838 (October); 1844 (November); 1846 (December); and 1851 (December). Kraska notes that many operative paragraphs of resolution 1838 were influenced by a meeting commissioned by the special representative of the secretary-general, Ambassador Ahmedou Ould-Abdallah, in the fall of 2008. Convened in Nairobi with the participation of diverse actors, the ensuing report suggested creating ship-rider agreements with countries situated to conduct investigations and prosecution, the enactment of legal structures in regional states such as Kenya, and the creation of an intelligence network. ${ }^{58}$

Meanwhile, resolution 1846 urged states to fully implement their obligations under SUA. By endorsing SUA the Security Council "resolved any doubt about the application of SUA to antipiracy enforcement off the coast of Somalia," 59 a call that was also made in the US National Security Council's Action Plan to counter piracy. ${ }^{60}$ The Security Council also explicitly engaged the UN Secretariat by requesting that the secretary-general report on ways to ensure long-term security off Somalia's coast and "a possible coordination and leadership role for the United Nations in this regard to rally Member States and regional organizations."

Two weeks later, the Security Council called for an integrated approach of efforts on land and at sea, and passed resolution 1851, which authorized the use of "all necessary measures," including on operations on Somali soil with the TFG's permission. By this time three multinational naval operations were underway led by the Combined Maritime Forces, EU NAVFOR and NATO-along with such independent deployers as India and Russia. To facilitate the coordination of military and other counter-piracy efforts, resolution 1851 also encouraged "all States and regional organizations fighting piracy and armed robbery at sea off the coast of Somalia to establish an international cooperation mechanism to act as a common point of contact between and among states, regional and international organizations on all aspects of combating piracy and armed robbery at sea off Somalia's coast." 61 With the passage of resolution 1851 in December 2008, Secretary of State Rice announced before the Security Council the intent of the United States to "work with partners to create a Contact Group on Somali Piracy." In her statement before the council, Rice noted three impediments to suppress the threat: weak state capacity, particularly among regional states; lack of political will; and an absence of coordination. ${ }^{62}$

The institutional configuration of what would become the Contact Group on Piracy off the Coast of Somalia has its roots in the US government's counter-piracy Action Plan. The hybrid-actor mechanism clearly reflects the George W. Bush administration's 2005 US National Strategy for Maritime Security: "Maritime security," it asserted, "is best achieved by blending public and private maritime security activities on a global scale into an integrated effort that addresses all maritime threats." ${ }^{13}$ The report further highlighted the conditions under which piracy and armed robbery at sea thrived: areas with significant commercial activity; high levels of political and economic instability; and weak maritime law enforcement capacity. ${ }^{64}$ Two years later, Bush issued an internal memorandum articulating a policy for the repression of piracy that emphasized interagency coordination within the US government and international cooperation, including by enhancing the repressive capacity of other states. ${ }^{65}$

As efforts were emerging within various UN bodies, the US Department of State began to actively develop an implementation plan to counter piracy in 2008, in the wake of Bush and Rice's attendance at an OPEC (Organization of the Petroleum Exporting Countries) meeting during which they had been apprised of the threat of piracy to oil carrying nations. ${ }^{66}$ Then Assistant Secretary of State for Political and Military Affairs Mark Kimmitt was asked to develop an approach to the problem, and he and other senior State Department officials decided to set up an international contact group on the issue.

Diplomats began reaching out to like-minded partners-France, Germany, and the United Kingdom-which together organized the initial conference and invited participation from states that were making concerted efforts, including through the deployment of military personnel/assets, or giving high-level attention to the issue. As Hopkins asserted, "The original intention was to involve only those countries that were willing to put 
resources into the problem." 67 Among those already active on the issue was Spain, which had conducted a highlevel meeting with France in 2008 to push forward an EU response to attacks on WFP ships, and subsequently set up a joint naval operation culminating in EU NAVFOR's Operation Atalanta in November 2008. ${ }^{68}$ The Republic of Korea (ROK) was also actively engaged, providing "strong support to the related resolutions adopted in the UN Security Council." The Korean government also hosted the Seoul High-Level Meeting on Piracy off the Coast of Somalia in June 2008, which included participation from 34 states and 16 international organizations. Thus "when the United States of America designed the establishment of the CGPCS in 2008," recalled Ambassador Hayong Moon, "the ROK was invited to the group as a contributor." 69

The selection process thus created a coalition of actors that not only had a common interest-initially the suppression of piracy and soon thereafter "the elimination of the scourge" - but also those that had demonstrated their willingness to actively contribute. As Hopkins notes, "It subsequently expanded to a whole universe of others who were interested in or affected by [the problem] . . . and international organizations."70

Denmark's Ambassador Winkler explained how his government became involved: "There were contacts from the US to us and of course also to others. There were some very informal discussions in New York; it was a classic diplomatic maneuver. The Security Council told us to get our act together . . . to coordinate better, and the US took the lead in that situation and called in a number of states that were either affected by piracy or had other interests in fighting piracy off the coast of Somalia." ${ }^{\prime 1}$

Broader engagement with other countries soon followed. At its first plenary session held in January 2009, a total of 24 states attended along with three regional organizations (African Union, EU, and NATO) and two UN bodies (the UN Secretariat and IMO). Actors from the region included: Djibouti, Egypt, Kenya, Oman, Saudi Arabia, the TFG, the United Arab Emirates, and Yemen.

The CGPCS was consistent with Security Council resolutions in its framing of the problem as a symptom of Somalia's weak state capacity. The CGPCS saw itself as a forum to facilitate discussion and coordination of actions to suppress piracy, a goal that was couched within broader international effort to "secure peace and stability in Somalia."

It noted five problems for the international community resulting from piracy:

1. disruption of critical humanitarian aid deliveries to Somalia;

2. increases in shipping insurance premiums to near-prohibitive levels;

3. damages to littoral economies from vessel diversion;

4. increased risk of environmental disaster, and;

5. threat to regional stability ${ }^{72}$

Six focus areas were identified as pertinent to the group's work:

1. "improving operational and information support to counter-piracy operations;

2. establishing a counter-piracy coordination mechanism;

3. strengthening judicial frameworks for arrest, prosecution and detention of pirates;

4. strengthening commercial shipping self-awareness and other capabilities;

5. pursuing improved diplomatic and public information efforts, and;

6. tracking financial flows related to piracy"73

The program of action, according to Hopkins, "was based largely on the White House National Security Council Countering Piracy Action Plan because the US had already started thinking internally about how we were going to organize ourselves to deal with this problem." 74 The program of work is clearly evident in the December 2008 
US Partnership and Action Plan, which articulated "five essential implementation pillars-improving operational and intelligence support to counter-piracy operations; strengthening judicial frameworks for detention and prosecution of pirates; disrupting pirate financial operations; strengthening commercial shipping self-defense capabilities; and pursing diplomatic and public information efforts to discourage piracy." ${ }^{175}$

In order to accomplish these goals, the CGPCS established four working groups (WGs). The structure, explains Hopkins, "is very closely aligned with our own US government internal organization." 76 WG1 was tasked with military and operational coordination and information sharing as well as the establishment of a regional coordination center; WG2 was to handle the judicial aspects of piracy with assistance from the UN Office on Drugs and Crime (UNODC); WG3 was to further self-awareness and self-prevention measures within the shipping industry with the assistance of the IMO; WG4 was assigned the role of improving diplomatic and public information efforts.

Although the idea for a fifth working group to address the financing of piracy had existed, it was not implemented at that time due to opposition from some states because of the sensitivity of sharing intelligence, which was thought to be a precondition for its work. ${ }^{76}$ WG5 was eventually established in 2011 at the contact group's ninth plenary session, following an ad-hoc meeting held by the United States.

The communiqué for the first meeting noted that the CGPCS had agreed to establish a small secretariat, although no further details were provided as to staff, location, or oversight in this communiqué or any following. Ultimately a team within the US Department of State's Political-Military Affairs Bureau would serve as the de facto secretariat along with each of the chairs of the working groups and the plenary chairs.

At the second CGPCS meeting in 2009, which had expanded to include 28 states and the Arab League alongside the African Union, the EU, and NATO, it was agreed that decisions would be made by consensus, that the working groups would not make decisions but rather recommendations through chairs' summaries that would be considered by the group as a whole. Chairmanship of the plenary sessions, moreover, would be rotated on a voluntary basis. The venue of those meetings was agreed to be UN headquarters, while a timetable was not established for meetings as these would be held on an ad hoc basis depending on the group's needs. Beyond these elements, there are few procedural guidelines for the CGPCS's conduct, including for "participation."

Indeed, the group began with "membership" and two criteria as to who could join: those states that had committed resources, such as naval assets; and regional states that were affected by Somali piracy. After the second CGPCS plenary in Cairo, these criteria were abolished, and any state with UN standing that was interested in joining could do so. There was also a discursive shift from "membership" to "participation," which was a means to sidestep thorny diplomatic issues, such as clashes between traditional rivals over the inclusion of a contested territory. At the same time, the abandonment of criteria also allowed non-regional states that were affected, including large seafaring countries such as the Philippines, to have a voice in the group. Winkler explains, "We have a procedure, developed more or less through custom, that if you as a state or organization want to apply, you should write to the chairman of the contact group, and the chairman will put it at the next meeting so we know who is joining." ${ }^{\prime 7}$ The inclusion of non-state actors, however, would prove far more contentious, as discussed below.

The CGPCS's only public documentation on its agreements and deliberations are the plenary session communiqués. These are made available by a website, developed by the Republic of Korea with assistance from the United States and the United Kingdom, which is the group's means of informing wider publics of its efforts to counter piracy. The CGPCS also has an official logo, proposed by the United States in 2009. The logo would come to symbolize the group's authority on this issue area and provide a stamp of legitimacy for the group in its program of work, which was both ambitious and far reaching. 


\section{Work and Outcomes of the CGPCS}

While the CGPCS's agenda is set by a small cohesive group that includes the chair of a particular plenary session, its practical work is carried out in the individual working groups. Participation at the working group level is very informal and access by particular actors is decided by the individual WG chairperson. WG 2 chair, Ambassador Winkler, explained it in this way: "The states and organizations who believe they can contribute to the discussions are welcome in my working group. We don't have a formal list of participants ... If a state comes to me or an organization can present a reasonable argument of why they can contribute and what they can contribute, then they are invited to be there." ${ }^{\prime 79}$

As noted above, each WG was tasked with a delimited scope of issues. Hester Somsen of the Security Policy Department of the Netherlands explained: "these quite clear issues and questions that all of our countries had because we were in this military operation ... that gave it some kind of impulse and working power that is quite unknown. ... The persons who have been heading the working groups, they had a tremendous drive to get things done." With a focus on what needed to be accomplished in the short term, the groups were "process and outcome oriented," she noted. ${ }^{80}$ This section unpacks the evolution of each WG's tasks and accomplishments as well as the establishment of the Trust Fund.

\section{Working Group 1}

WG1, chaired by the United Kingdom and largely hosted by the IMO at their London headquarters, was initially tasked with coordinating naval operations and soon adopted capacity building as its second main area of concern. The group brought together military, industry, and government representatives, providing a forum for the exchange of views and concerns between naval forces and civilian actors. WG1, according to its current chairman James Hughes, regularly gets about a hundred people at a meeting. He noted that the majority of CGPCS country participants attend WG1 gatherings alongside IGO and industry representatives. Of key importance to WG1 activities is the regular participation of military officials from SHADE. ${ }^{81}$

The SHADE mechanism, which the Combined Maritime Forces launched in December 2008, ultimately evolved into the de facto forum for naval coordination, with the CGPCS acting as a venue for briefing by SHADE tactical and operational commanders and as a source of political support. SHADE includes military and civilian representatives from 27 countries, 14 intergovernmental organizations, and the shipping industry. The development of SHADE, however, was "not a foregone conclusion," as WG1's first chair Ambassador Chris Holtby explained. "Some partners did not want to be involved in the joint patrolling," he noted, and there was "real resistance to joint command and control." ${ }^{82}$ WG1, however, provided a forum for various military actors to share their activities and plans, which in turn fostered trust-building. China, for example, had early on advocated the creation of an alternative to the Internationally Recommended Transit Corridor (IRTC), on a separate route and with protection provided by convoys rather than by area patrolling, but recognized the advantages of cooperation through SHADE and joined before long. The structure of the SHADE mechanism was designed to be sensitive to the concerns about sharing command and control activities. As the name itself makes clear, it is a process designed to reduce duplication or mission conflict through information sharing. It is a mechanism for shared awareness-not joint military operations.

Over time, WG1 and SHADE would mutually influence each other's development. ${ }^{83}$ As Hopkins explained, SHADE "became the center of gravity for naval coordination, because it needed less political support over time." "One of the great successes of the whole contact group," she remarked, "was how it politically supported the development and evolution of the SHADE mechanism for operational coordination." ${ }^{44}$

According to Holtby, WG1 recognized early on the need to develop a forward-looking approach, and the group took on an additional role, namely, maritime security capacity-building in Somalia and other littoral states. 
During the working group's very first session, regional capacity-building was deemed to be the "most sustainable solution" to the phenomenon of piracy. ${ }^{85}$ In order to achieve this aim, an assessment of need was generated so that donors could target their efforts effectively. An important role of WG1 was to identify gaps and monitor progress on program implementation. In June 2009, the United Kingdom unveiled an assessment of coastguards, naval/military structures, and judicial and penal detention centers. The UK-led and funded this initiative in coordination with the IMO, European Commission, UNODC, UNPOS, Somali authorities, regional governments, and a number of other CGPCS participants.

According to the initial assessment, although Somali land-based governance/law and order structures and economic/alternative livelihood programs fell "beyond the sole direct responsibility of the CGPCS . . close coordination/cooperation/deconfliction with planning/activity in these areas is essential to the greater effectiveness/success of counter-piracy related programs." ${ }^{86}$ Despite significant bilateral efforts including the production of an interactive matrix of needs that mapped current and planned activities and helped ensure a core objective of transparency, action was not fully coordinated and prioritized. In the meantime, the EU had moved to implement EUCAP NESTOR, the civilian complement to its military deployment, which focused on building maritime capacity among five countries in the Horn of Africa and the Western Indian Ocean. ${ }^{87}$

Under the chairmanship of James Hughes, WG1 has set up the Capacity-Building Coordination Group (CBCG), facilitated jointly by the EU, IMO, and a regional organization on a rotational basis. The aim is to replicate SHADE's informal and non-bureaucratic working methods and facilitate information sharing among those people and institutions working on capacity building. By meeting regularly the CBCG intends to avoid effort overlap, to flag and fill gaps in ongoing and planned capacity-building activities, and to provide an opportunity for regional beneficiary countries and Somali regions to define their needs directly to donors and implementing organizations. Its interfacing with WG1 would provide a source of political support.

To give impetus to the project, the role of creating an online coordination platform was entrusted to a nonstate actor, OBP. The idea was to replace the existing paper-based WG1 Regional Counter-Piracy Capability Development Needs Assessment Matrix with a more interactive, online tool. OBP developed the WG1 CapacityBuilding Coordination Platform in close cooperation with key capacity-building organizations, donor countries, and beneficiary states and officially launched prior to the WG1 meeting in Addis Ababa in March 2013 after a period of preliminary testing in the fall of 2012 and early 2013. Hughes explained that the dynamic online interface that facilitates examination of needs, current plans, and executed projects has facilitated greater use of the WG1 matrix, thus furthering the goal of coordination. ${ }^{88}$

\section{Working Group 2}

WG2, chaired by Denmark, set out to examine the existing legal basis for combating piracy. As Winkler noted, "From the outset there was actually a quite good legal basis in international law, but we still needed to identify it, interpret it, to get a common approach to what was actually in the legal framework." However, he noted, that "some answers we have found in international law but most answers have to be found in national law." ${ }^{89}$ WG2 thus set out to investigate how national criminal procedural norms and rules hamper criminal prosecution.

WG2 examined practical impediments to prosecution (e.g., collection of evidence to meet evidentiary standards) and developed a "checklist" of proactive measures that states could take to ensure their ability to prosecute suspects. It gathered information on "relevant national legal systems," working closely with UNODC's Counterpiracy Programme (CPP), which was launched in May 2009 and is devoted to the construction and modernization of prisons and courtrooms in Kenya, Seychelles, Mauritius, and Somalia and the overall facilitation of judicial processes. $^{90}$ 
The group functioned as a forum for an exchange of lessons learned in the areas of evidence collection and handling, securing testimony from witnesses, and issues related to detention. An early WG2 accomplishment was the creation of a "legal toolbox" containing guidance on various legal aspects of counter piracy activities. This collection of documents includes templates for ship-rider agreements, guidelines for the collection of evidence, and templates for bilateral pre-trial and post-trial transfer agreements (discussed below).

In addition to clarifying the existing international legal framework and providing practical legal guidance, a core issue for the group to tackle was to find a solution to the problem of detaining, prosecuting, and incarcerating pirates. An early preoccupation was deciding whether or not to create an international tribunal or a regional mechanism to fill the gap in domestic capacity. By early 2010, WG2 had considered "the most feasible model would be a specialized or dedicated piracy chamber-with or without international elements-established within the existing domestic criminal justice system of one or more states and in one or more states willing and able to undertake prosecution." ${ }^{11}$

Yet the issue of appropriate mechanisms to address the issues of imprisonment and prosecution continued to be debated. In June 2010, France re-launched a Portuguese proposal from November 2009 for a special Somali court that would be located in a state in the region and be supported internationally. ${ }^{92}$

In June 2010, the UN Security Council took action on the issue and in resolution 1918 requested the UN secretary-general to produce a report detailing possible options, which would take into account the CGPCS's work. In his July 2010 report, the secretary-general presented seven options, including special domestic chambers, the establishment of a Somali court situated in another state in the region, a regional tribunal, and an international tribunal established under Chapter VII of the UN Charter. The report weighed the advantages and disadvantages of each option, noting that an international tribunal would "not likely to be among the most cost-effective." Moreover, as Annex II of that report regarding CGPCS discussions noted "the crime of piracy is of a different nature and scope to the serious international crimes normally dealt with by international tribunals, and that suspected pirates brought before any such new international tribunal would be unlikely to meet the criterion of being the 'most responsible' for the crimes in question, which is a threshold applied by most of the current international tribunals." ${ }^{93}$ Other options raised by the CGPCS were considered infeasible. They included amending the Rome Statute of the International Criminal Court, an amendment to the International Tribunal, and the amendment to the statute of the African Court on Human and Peoples' Rights.

The report's summary highlighted some success of the already ongoing efforts of its first option-the enhancement of UN assistance to build capacity in regional states to prosecute and imprison pirates. The report concluded that any of the other six options would require consideration of "the need for sufficient political and financial commitment among States, in difficult economic times, not only to establish a new judicial mechanism, but also to sustain it .... Such a mechanism would face ongoing criminal activity and potentially a large caseload, with no predictable completion date." ${ }^{\prime 4}$

In November 2010, states participating in WG2 agreed the international community should proceed with option 1 , although it would continue to consider possible mechanisms with the UN secretary-general's newly appointed special advisor on legal issues related to piracy off of Somalia's coast, Jack Lang.

In his 2011 report to the UN Security Council, Lang proposed "implementing a legal system that [would] include the establishment of a Somali extraterritorial jurisdiction court in Arusha and two special courtsone in Puntland and the other in Somaliland-and, finally, the construction of three prisons in Somaliland and Puntland," which France publicly supported. ${ }^{95}$ According to media reports, Somalia objected to a court in Tanzania, while others expressed concerns about the viability of a Puntland-based court owing to alleged connections between local authorities and pirate bosses. ${ }^{96}$ 
By this time, WG2 had facilitated a number of pre-trial transfer agreements that included Kenya, Seychelles, and Mauritius, and had been working on the issue of post-trial transfers to fill in gaps in incarceration capacity. Transfer agreements were developed to move pirates that were prosecuted in one territorial jurisdiction to another. These would take the form of bilateral agreements between prosecuting countries that lack the capacity to incarcerate Somali pirates and Somalia, as well as other regional countries willing to imprison them. Already in February 2011, such an agreement had been made between Seychelles and the TFG, which would serve as a legal model. With the April 2011 Memoranda of Understanding between Seychelles and Puntland and Seychelles and Somaliland, the WG2 had effectively expanded the legal framework for the transfer of individuals originating from Somalia.

Human rights issues were a consideration for WG2 participants from the outset. Indeed, the very emergence of UNODC'S CPP stemmed from concerns among some naval deploying countries about violating their human rights obligations by turning over pirates to countries where trials and/or detention would not meet standards to which they are bound. UNODC CPP regional coordinator Alan Cole explained:

The particular interpretation that many EU NAVFOR members states put on their legal obligations is that they have a legal liability if they transfer people for trial in a third country and that trial doesn't meet certain international standards. So they were very keen to arrest Somali pirates, and they were very keen to see them prosecuted in the region rather than back in Europe, but they were also keen to make sure that there was a mitigation strategy in place to ensure that the trials were fair and that any period of imprisonment met international standards. And the UNODC Counter Piracy Programme came about as a mitigation strategy. So they effectively said to UNODC, 'We want you to take that risk away from us, or ensure us against that risk by running a program which will make sure that the trials are fair and the imprisonment is secure and humane.' So that is what UNODC did. ${ }^{97}$

Yet Winkler has noted that more work still needs to be done concerning human rights. One of the critical areas is in the handling of juveniles. ${ }^{98}$ Most pirates are under the age of twenty-five, according to Cole, and a number those who have been transferred for trial have been under the age of 18 , which have raised issues for prosecuting states. ${ }^{99}$

Overall there has been considerable progress on ending impunity. UNODC had counted almost 1,180 suspected pirates who were being held in 21 states, most notably in Kenya, Somalia (especially Puntland), Seychelles, Yemen, and India by late 2012.

WG2 also established the legal framework for an international trust fund, the purpose of which was to defray the expenses associated with the prosecution of pirates and related activities. The administration, board membership, capitalization, and project financing of the CGPCS Trust Fund are discussed in a separate section below.

WG2 has also grappled with perhaps the most contentious issue within the CGPCS: the use of privately contracted armed security personnel (PCASP). The legality of PCASP is ultimately decided by flag states; however, complications arise with port state policies on the presence of arms on board foreign ships docked in their jurisdiction. While discussed within WG2 in terms of the legal aspects, this issue has been a core aspect of WG3's work.

Working Group 3

WG3 was initially co-chaired by the US Coast Guard (USCG) and Maritime Administration (MARAD), with support from the IMO. One of its major goals was to increase communication among industry, labor, and government. Working closely with industry, it gathered "lessons learned" among those involved with pirate attacks and disseminated these within the maritime community. In its efforts to enhance shipping self-awareness, it aimed 
to further the Best Management Practices (BMPs) developed by industry and supported by MSC-HOA, UKMTO, and MARLO. Hinchliffe explained:

The BMP was written by a group of industry associations including ICS, and it was up to us to get it endorsed by and implemented by shipping companies ... We drove implementation up to probably what was around 75 to 80 percent of all ships in the region [that] were complying to a greater or lesser degree with the BMP. . . We turned to governments because there seemed to barrier beyond which we couldn't go ... We did go through the contact group and brief the contact group on the BMP and what it was aiming to do and why we felt that it was up to flag states to take more action to make sure that the ships flying their flag were actually compliant. ... We did the same kind of activity at the IMO ... There was a difference in what the two bodies could do. IMO was able to accept a resolution which was largely drafted by the industry which does put the onus on flag states ... The contact group could never do that. ... But ... the original declaration by flag states .... was done under the aegis of the contact group at one of the early meetings in New York. ${ }^{100}$

WG3 reviewed BMP implementation and disseminated Piracy Counter-Measure Guidance. By late 2009, the initial set of BMPs submitted to the IMO had reportedly been received by "the vast majority of world shipping." 101 The CGPCS was also the forum for the signing of the New York Declaration of commitment to the BMPs among the Bahamas, Liberia, and the Marshall Islands in May 2009, with an additional six states, including the United States, signing on in September.

Part of WG3's efforts concerned information gathering on BMP adherence by flag states. At the fifth plenary session chaired by Norway in January 2010, it was estimated that 90 percent of vessels were following the BMPs, although efforts were being undermined by a lack of reporting to MSC-HOA and UKMTO. During the sixth plenary in June 2010, WG3 reported that BMP implementation is voluntary in most countries. In an effort to increase compliance, MSC-HOA developed procedures to notify flag states of ships that are not implementing the "appropriate preventive measures."

One of the most contentious issues within WG3 revolved around PCASP, which in mid-2010 were mostly prohibited by flag states. The United States was an early champion of PCASP, which seems to be gaining traction among other states that were initially opposed to their use on commercial vessels. A few countries have gone as far as changing domestic legislation to allow for PCASP on board merchant ships. Some countries within the region remain resolutely opposed, particularly on the issue of floating armories near their territories. Under the UAE's chairmanship of the CGPCS in March 2012, for example, the concerns of some coastal states in the Indian Ocean "about the increasing use of armed guards by commercial ships in the proximity of such states" were noted, and both WG2 and WG3 were tasked to address related concerns. Within WG3, guidelines were developed and turned over to the IMO for endorsement.

After three years of US leadership, discussions arose on passing leadership to a non-European country, and the Republic of Korea volunteered in early 2012. Since then, WG3 has increasingly paid attention to the issue of seafarer welfare, which was noted as early as 2009, perhaps a reflection of the growing role of NGOs concerned with seafarers. In particular, the Maritime Piracy Humanitarian Response Programme (MPHRP) has been actively involved in this work as part of WG3. MPHRP is an NGO funded by the International Transport Workers' Federation Seafarer's Trust and the TK Foundation that aims "to implement a model for assisting seafarers and their families with the humanitarian aspects of a traumatic incident caused by piracy attack, armed robbery, or being taken hostage to be offered as an integral part of the Emergency Response Procedures of shipping companies and manning agencies in cooperation with partners involved in seafarers' welfare."102 
Working Group 4

WG4, chaired by Egypt, was tasked with examining "ways to disseminate the CGPCS message to the identified target audiences, while emphasizing the role of the United Nations Political Office in Somalia in this regard." One of its initial tasks was to "examine a potential role for a Press and Media Officer within the Secretariat of the CGPCS." ${ }^{103}$ However, it does not appear that such an initiative was undertaken. Owing to its critical role within Somalia, UNPOS took the leading role on coordinating communications.

WG4 appears to have had more serious challenges in their operations than other working groups, which interviewees have attributed to various factors: complex political challenges; a vague mandate and program of work; and security concerns that hamper an on-the-ground communications strategy with Somali communal leaders.

"Messaging is a lot harder to organize than you would think," explained OBP's director Jon Huggins. As WG4 continues to deal with the challenges associated with messaging, The United States, the United Kingdom, Denmark, and even non-state actors such as Oceans Beyond Piracy (OBP), have taken a voluntary role to support the WG4's work, bringing together relevant stakeholders to discuss and coordinate public information and strategic messaging within Somalia and to the international community. Huggins envisions four necessary steps to enhancing its effectiveness. The first is to increase transparency about who is messaging and what is being messaged. The second concerns deconflicting the messages that are being broadcast from a number of different actors with different underlying interests. The third is coordination; and the final step is to generate messaging that supports the group's overall counter-piracy strategy. ${ }^{104}$

The overall assessment is that much work remains to be done on this aspect of the CGPCS's efforts in shaping local perceptions, but that the increased frequency in WG4 meetings and workshops has reinvigorated this working group and brought in a wide range of state and non-state groups.

\section{Working Group 5}

Chaired by the Italian government's Giuseppe Maresca of the treasury department, WG5 met for the first time in 2011 and is thus only now gaining speed. Debates surrounding the establishment of the working group centered on the issues of duplication and feasibility. One area of concern for WG5 is to examine how ransom money flows. Along with the UNODC and INTERPOL, a key participant is the World Bank. Together these organizations have undertaken an extensive joint study on this issue. WG5 is also investigating how information can be used to prosecute pirates. One of its goals is to improve information sharing and cooperation between the private sector and governments. To further this goal, the United States National Central Bureau developed a Global Maritime Piracy database to be entrusted to INTERPOL, ${ }^{105}$ which launched the Evidence Exploitation Initiative (EVEXI) project in 2011 with funding from France and Norway. ${ }^{106}$

Maresca has noted some discernible progress on achieving an agreement among the 30 or so countries that participate in the group. "The first step is almost reached," he asserted, "to have an agreement on a document that we can call principles on information sharing on piracy and that involves the agreement to set up a single point of contact at the national level. And that is the basis for having a more fluid flow of information between government and industry. Once we have an agreement on principles then we will work on filling the principles with practical details so that it can be applied successfully." At the international level, INTERPOL is partially fulfilling this role. However, according to Maresca, "it is a matter of formalizing this role of INTERPOL and to make sure that INTERPOL has the resources to manage this role." The development of principles and implementation mechanisms, he asserted, "is very close." ${ }^{107}$ 
The Trust Fund

The CGPCS endorsed the International Trust Fund at its third meeting in May 2009 in New York. Established as a voluntary mechanism open to contributions from governments, industry, and others, the fund seeks to "help defray expenses associated with the prosecution of suspected pirates and other activities related to implementing contact group objectives." In addition, the fund also finances "other priority activities," particularly public communications initiatives. Keeping in line with the Trust Fund's Terms of Reference, only UN organizations have been recipients of the fund: UNDP, UNODC, and UNPOS. ${ }^{108}$

From the outset, the UN "offered to provide assistance to administer the fund," and in January 2010, UNODC became the fund manager. By placing the fund under UN oversight, it facilitated national contributions, transparency, and accountability. Yet UNODC encountered difficulties in managing the fund and that responsibility was shifted to the UNDP. The UNDPA chairs the fund's board.

The board consists of ten CGPCS states, which are "chosen on the basis of substantial contributions made to counter-piracy efforts." Three seats are allotted to states from the region, while the other seven are rotated among like-minded donor countries for two-year terms. In 2013, Germany, Italy, Kenya, Republic of Korea, Norway, Qatar, Seychelles, Somalia, Turkey, and the United Kingdom serve as CGPCS board members. ${ }^{109}$

By June 2010, the trust fund had approved seven projects, six of which concerned strengthening prosecution in Seychelles, Kenya, Somaliland, and Puntland. The seventh concerned strategic communications dissemination with local partners concerning anti-piracy messages. By the end of 2012, the fund had received \$16.5 million, and $\$ 12.12$ million had been dispersed for a total of 27 approved projects. The UNDPA's Amit Singhal noted that the Trust Fund's Expedited Facility Mechanism works remarkably well. It permits the payment or reimbursement of short-term prosecution-related expenses such as legal capacity-building activities, which are undertaken in consultation with actors on the ground. ${ }^{110}$ The CGPCS's own website hails it as "an efficient and rapid instrument." 111

\section{Impact of International Efforts on Filling Gaps}

By December 2012, it seemed apparent that something had changed in the piracy arena: the number of successful pirate attacks dropped substantially, from 176 in 2011 to 35 by the end of 2012; and ransom payments declined by approximately 700 percent during that period. While disentangling the causes of this drop may be complicated, it appeared that the concerted efforts of more than 60 governments along with more than 20 IGOs, NGOs, and private associations had registered success in suppressing piracy off of Somalia's coast. This section analyzes how the CGPCS's work has contributed to the development of a robust anti-piracy regime, which results in coordination and cooperation among diverse actors.

As a network, it is a challenge, as Hughes notes, "to put your finger on what the CGPCS delivers itself, as an entity." While "there are different schools of thought about the extent to which the CGPCS delivers anything," this analysis finds evidence of concrete achievements and instances in which "the CGPCS has facilitated the discussions and conversations and encouraged participants to act" although individual stakeholders ultimately make their own decisions. ${ }^{112}$ Returning to Weiss and Thakur's lens of global governance gaps, we can assess in what ways the CGPCS has rendered the initiatives of diverse stakeholders more than the sum of their individual efforts. In using such a framework, moreover, the analysis can extract lessons for initiatives to tackle other global problems.

Knowledge of the Problem and Challenges

From the outset, participants recognized the need for "better operational information in order to address the problem of piracy." To this end, it called on "members" to contribute information as well as surveillance assets to 
the region. ${ }^{113}$ The CGPCS has not only advocated for more robust information gathering and sharing, but it has also acted as a crucial forum for exchanging ideas and concerns among various actors on the issue of counterpiracy.

Shoichi Nagayoshi of the Japanese Ministry of Foreign Affairs' Maritime Security Policy Division noted how "difficult it is to put in broader perspective with regard to counter-piracy activities conducted both bilaterally and multilaterally." The contact group, he asserted, "is the very best platform for countries and organizations concerned to have a comprehensive picture of those activities ... and [that] helps us to formulate our own policies." ${ }^{114}$ The UK's James Hughes similarly noted:

The CGPCS informs and influences our national thinking across the board on counter-piracy activity in the same way that our positions expressed in the CGPCS help influence other people's thinking within the CGPCS. Because it is an information sharing, awareness raising mechanism, we all bring our own different perspectives to the table; we all listen and benefit from those different perspectives, take them back, and upon reflection we may actually embed what we hear and learn into our own thinking. ${ }^{115}$

The CGPCS thus provides a forum for "open, unencumbered debate among like-minded governments principally and other stakeholders." ${ }^{116}$ With participation from commanders in CMF, EU NAVFOR, and NATO, civilians and military officials from a wide range of states have an opportunity to generate shared awareness of challenges to practical implementation on both sides. Meanwhile, advocacy NGOs shed light on the plight of seafarers and their families, making states and others aware of the human dimension of the problem. Industry has provided input into guidelines on PCASP. On these issues, Winkler noted that "when the diplomatic lawyers are working out guidelines it is extremely useful for industry to say this is not workable or have seafarers saying what about the interests of the seafarers with all these guys running around with arms on the ship." ${ }^{117}$ David Rider of the Seamen's Church Institute $(\mathrm{SCl})$ called the process one of "pooling wisdom" on various facets of the issue. ${ }^{118}$

Yet progress in other areas of the CGPCS's work seems to have inadvertently widened a gap in information sharing, particularly as it relates to industry reporting of attacks. Some speculate that there is increased hesitancy on the part of industry to report attacks, particularly when PCASP are involved because of concerns about legal liability. In one of the few cases where such underreporting is documented (albeit contentiously), a Yemeni fisherman was killed in 2011 by shots apparently fired from a passing tanker-although the CEO of the company that owns the ship accused of firing on the fisherman strenuously denies that any shots were fired from his ship. ${ }^{119}$ Another incident was reported by the UN Monitoring Group on Somalia and Eritrea in its report from 2011 in which a whaler with six suspected pirates was intercepted and a skiff containing a dead body with a gunshot wound was found by naval forces in close proximity to a merchant vessel that had sent out a distress call a few hours earlier. However, the ship's master denied any presence of armed guards or weapons on board his ship and declined to file a report against the suspected pirates who were subsequently released. ${ }^{120}$

In late 2011, with the increased use of PCASP, the CGPCS communique "stressed the need for a more effective dialogue with the shipping industry and related private sector organizations to further improve the exchange of information, especially to ensure that national authorities received detailed reports on piracy cases in a timely fashion." ${ }^{121}$

One achievement of the CGPCS has been to elucidate the existing legal framework available to grapple with piracy. As Winkler noted, "We have gone from a situation in which there was very little knowledge or clarity on the legal issues to a situation where there is much clarity." One clear product bearing the CGPCS brand is the "legal toolbox," which is available to all contact group participants online and contains legal guidance on counterpiracy activities. Winkler notes that there are few if any questions that are not answered in the toolbox. ${ }^{122}$ 
A number of interviewees singled out the WG2 toolbox as an important accomplishment in addressing an extremely complicated legal situation, which was captured succinctly by Swarttouw as one in which there could be as many as seven countries involved in a specific incident. There could be, he noted, "a ship owned by country $A$, flying the flag of country $B$, with a captain from country $C$, and a crew from country $D$, sailing in the waters of country $E$, being hijacked by pirates from country $F$, who are being arrested by a naval vessel from country G, et cetera."123

Knowledge has also been generated about legal gaps both among deploying states and regional actors, as well as capability gaps among the latter. This information gap was filled through the in-depth investigations of various UN organizations and working group chairs. The identification of specific gaps facilitates the targeting of resources to meet collective efforts to end impunity. On the practical side, INTERPOL, among others, has offered guidance on evidence collection and investigation procedure.

One of the primary functions of global institutions is to facilitate the exchange of ideas and generate and distribute information and analysis. The CGPCS has played this role by gathering interested stakeholders at its regular plenary sessions and working group meetings, encouraging information sharing, and developing a shared understanding of the problem and challenges associated with counter-piracy.

Legal Developments at the International and Domestic Levels

By first identifying legal gaps, CGPCS has sought to close them at both the international and domestic levels. Working through the UN Security Council, leading states sought to fill loopholes in the existing legal framework and extend enforcement powers into the territory of Somalia under Chapter VII of the Charter.

At the national level, the contact group encouraged the implementation of national legislation that would ensure the prosecution of pirates. As reported to UNODC, a number of states began to amend their legislation to criminalize piracy. A number of governments have also moved to legalize PCASP on their flagged vessels, a sign of growing convergence on the legitimacy of allowing private armed security forces aboard commercial ships. However, as Swarttouw explains, this may be a result of ship owners lobbying their national governments rather than the influence of the contact group. ${ }^{124}$

In either case, consensus on this issue is still very distant. As it is now private armed companies require the permission of each state to go into port and transit territorial waters. While some have suggested a regional agreement, "it would be very difficult to get any sort of agreement around the Indian Ocean," explained Winkler. ${ }^{125}$ While there is "no quick fix," floating armories have been used by private companies to get around the complicated legislation of the coastal states. Not only is the legality of such floating armories in international waters unclear, but the practice raises concerns about whether they might add to the very problem that they are meant to stop owing to their vulnerability to pirate attacks if not properly secured..$^{126}$

From the outset, there has been consensus that self-protection measures for ships are crucial to countering piracy. To this end, the CGPCS has strongly promoted the industry produced BMPs and encouraged states to incorporate them into domestic law or at least to advocate their use on vessels in their registries. As noted above, the contact group also served as the impetus for the New York Declaration in which major flag states committed to self-protection measures as a means to counter-piracy in compliance with their International Ship and Port Security Code (ISPS). In addition to key open registries, Cyprus, Japan, Singapore, the United Kingdom and the United States are signatories.

Given the nature of the contemporary world order, the CGPCS faces limitations similar to the UN or other international bodies: "While the source and scale of most of today's pressing challenges are global and any effective solution must also be global, the policy authority for tackling them remains vested in states." ${ }^{127}$ The 
CGPCS does not make policy, although it can influence the policy choices made by national governments, nor does it make binding decisions. However, declarations and other statements of shared general principles can begin as nonbinding statements of shared belief but can later serve as the basis for legal claims against actors that violate such statements once they have been more broadly accepted. ${ }^{128}$ The CGPCS has primarily focused on coordinating the activities of stakeholders rather than generating agreed principles. It did, however, facilitate the New York Declaration, a document intended to shape national policy, suggesting that it may play such a role in the future.

Generating Political Will to End Impunity

The actual implementation of obligations stemming from existing international treaties was seen as crucial in efforts to suppress maritime crime as was generating political will from within Somalia and in the region more broadly. Consistent with the legal changes discussed above, the prosecution and incarceration of pirates increased. The record on prosecutions reveals progress both within and outside of the region. As shown in Figure 3 , there is a direct relationship between proximity to the Gulf of Aden and the willingness of countries to try pirates. African states have taken the primary responsibility for both holding and prosecuting suspects, followed by Asian and Middle Eastern states, European states, and North America. For 2010, the first year where we could identify solid numbers, there were a total of 736 suspects held and 507 prosecuted across all regions. Numbers of suspects climbed steadily in 2011 and 2012. Prosecution numbers followed suit, although incomplete information about prosecutions in 2012 undermine our ability to analyze shifts in prosecutions.

\section{FIGURE 3: Geographic and Temporal Distribution of Piracy Prosecutions ${ }^{129}$}

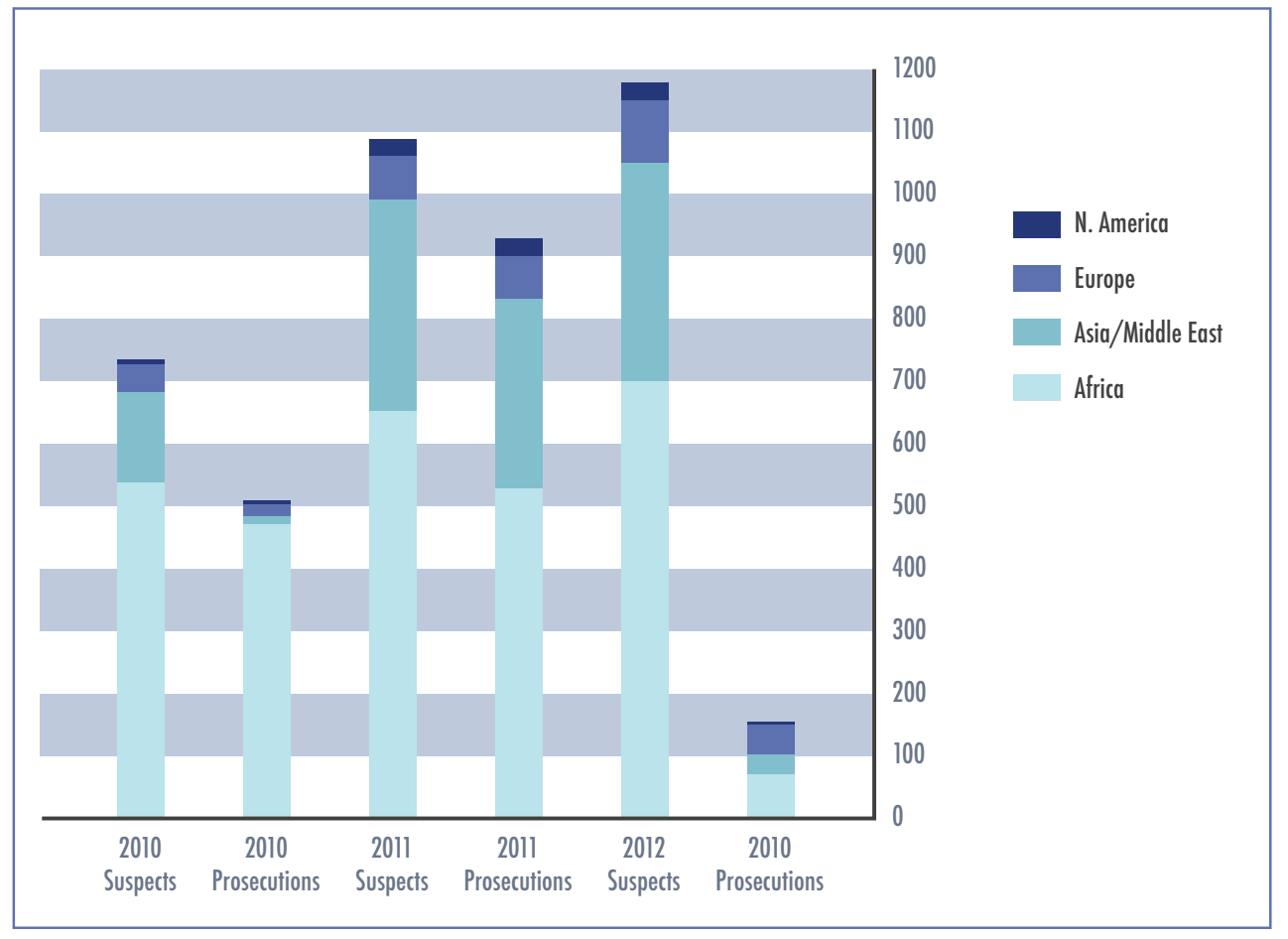

The CGPCS's ability to mobilize action is relatively weak. Treaty-based international law, such as the Rome Statute, which created the International Criminal Court, places specific enforceable obligations on the signatories that affect internal calculations about the cost and outcome of policy decisions. The CGPCS lacks such strong enforcement mechanisms by design. However, despite its lack of authority, the numbers above suggest that the CGPCS has been successful in impacting the policy decisions of its participants.

The CGPCS has also affected the practices of non-state actors. As discussed above, WG3's and IMO's aggressive promotion of the BMPs has driven compliance to an estimated 90 percent. Moreover, Hopkins notes that "the 
180-degree reversal of industry's initial opposition to [the] use of embarked armed security is largely attributable to their pragmatism and the implied, if not universal, political support for the use of embarked armed security discussed in great detail from every angle in various CGPCS meetings." ${ }^{130}$ In turn, industry has collectively sponsored (through the International Shipping Round Table) the Save Our Seafarers campaign to raise public awareness and pressure governments to do more to address piracy.

Institutional Development

The initiatives of the contact group have fostered institutionalization at the international and domestic levels. The CGPCS fills an institutional gap in its own right, not only as a forum for sharing ideas and problem solving but also in spreading the costs of collective action. Among states, as Winkler described, "It is a burden sharing with international naval forces picking up the pirates, states in the region, including Kenya and Seychelles, prosecuting the pirates, and then Somalia of course, with our assistance, handling the incarceration. It's a now wellfunctioning circle of prosecution." 131 The establishment of this circle has been possible because of the CGPCS's legal guidance as well as the trust fund's financing of relevant capacity building projects in regional states and offsetting of costs associated with prosecution such as transporting witnesses. In addition to facilitating cost sharing, it has also cultivated trust, interpersonal and formal organizational networks, and other voluntary coordination mechanisms.

The regular meetings of CGPCS, particularly the working groups, have generated trust among a number of key actors. The iterated nature of the meetings provided an opportunity for participants to slowly build trust through interaction. Initially, noted Hopkins, "There was also a lot of political resistance among some countries to doing things at what appeared to be the bidding of the western powers running the contact group."132

When asked why some countries that might be expected to become involved have not, Swarttouw explained:

Perhaps because of the different ways bureaucracies and diplomacy are organized. Those with less experience with this informal way of working may have insecurities because there are no formal rules and procedures. In the beginning, we saw countries like India, China, and up to a point Russia in the first five or six meetings, they were waiting and watching to see what kind of organization this was or was going to be, and repeatedly suggesting that this cooperation should be more institutionalized or formalized but as we went along they stopped saying that, perhaps because they realized that it would become less effective. For countries like the Netherlands, Denmark, the US and UK, we are so used to working together in all kinds of ad- hoc coalitions and others countries have less experience with that way of working and perhaps feel insecure about it. We managed to dissipate those feelings. ${ }^{133}$

WG5 has made an effort to engage in trust-building between industry and governments. It has addressed industry concerns that information sharing could complicate efforts to secure the return of hijacked ships and hostages through ransom payments. Maresca explained,

They are not confident in government because of unwilled publicity that may be given to specific details. Another thing that they are afraid of is that information that they are sharing may backfire on them. For example, they have been discussing with the US government about the possible decision on prohibiting dealing with pirate groups. There have been several discussions, and there is now a better understanding between the parties. It is prohibited for a US citizen to pay money for any reason to terrorists or people involved with terrorists. Some of these pirates may be linked to terrorist groups, and this is where the concerns of ship owners has become more acute.

He further asserted: "We make clear that we are taking account of the specific challenges of industry; information wouldn't be used to increase their own difficulties, or jeopardize their commercial interests."134 
In addition to enhanced trust among a number of countries and between governments and industry, NGOs such as OBP have acquired trust among key states and industry actors. This has allowed OBP to act as a broker between core states and other states and between states and industry, which as mentioned above, is sometimes guarded about sharing information on sensitive issues.

This discussion of how information flows between trusted actors illustrates another feature of the contact group. CGPCS participation, as Rider described, is one of "classic networking." ${ }^{135}$ The fostering of connections among various actors has created an informal network alongside the more institutionalized relationships among the various actors. As Nagayoshi explained, "It's useful for us to know each other, who are involved in activities to counter piracy." ${ }^{136}$ Similarly Swarttouw noted how the CGPCS has cultivated "virtual networks of people from different walks of life (e.g., national bureaucracies, international personnel in the field, industry, NGOs) who know how to contact each other." Interpersonal networks are especially crucial for information sharing, which requires trust among those engaged in exchange as exemplified above by Maresca's remarks.

In addition to trust building and the facilitation of networks, the CGPCS has served as an institution that could facilitate issue-specific coordination mechanisms. As Norway's Carl P. Salicath explained, the CGPCS's achievements are many, one of which is serving as "a place to anchor SHADE politically." ${ }^{137}$ Similarly, the GCPCS is fostering the emergence of a capacity building group akin to SHADE. In this way, CGPCS working groups, especially WG1, have furthered the development of coordination mechanisms in specific issue areas related to counter-piracy off of Somalia's coast.

The CGPCS is not formally institutionalized and thus its fluid network structure and lack of terms of reference or standing secretariat means that it can be easily dismantled unlike organizations with significant bureaucratic and physical infrastructure. Some participants have noted that as a positive feature, asserting that formal bodies can outlive their initial purpose as vested interests ensure their perpetuation. These are the same characteristics that have allowed the CGPCS to be nimble and effective, and they have facilitated the institutionalization of counterpiracy activities within established organizations and within state bureaucracies.

Within the UN, a coordination mechanism was established under the leadership of the UNDPA that entails regular meetings among relevant organizations, including such core IGOs in the counter-piracy campaign such as the IMO, UNDP, UNODC, UNPOS, as well as UNDPKO, the WFP, the Food and Agriculture Organization, and the Office of the High Commissioner for Human Rights. The UN Secretariat also created a post of special adviser on legal issues related to piracy off the coast of Somalia. Within the UNODC, a counter-piracy program was established.

INTERPOL also created a Maritime Piracy Task Force (MPTF) in January 2010. According the task force's head, Pierre Saint Hilaire, the MPTF focuses on "pirate leaders, organizers, negotiators, and investors" 138 and thereby fills an important institutional gap that also plugs knowledge gaps about pirate networks.

At the domestic level, governments have culled staff from various ministries and departments to tackle this issue. As Hopkins explained of the US government's Bureau of Political and Military Affairs Counter Piracy and Maritime Security team, "We ... morphed into an actual office ... It was becoming labor intensive. Now we have an office of nine people who concentrate on Somali piracy, a large part of our job has to do with furthering the work of the contact group." ${ }^{139}$ Other examples include Norway, which now has an inter-ministerial task force devoted to the issue, and Spain, which has created an ambassador post to head a counter-piracy unit that focuses almost exclusively on the Horn of Africa. 


\section{Compliance Mechanisms}

The CGPCS emphasizes that "all countries bear the burden of piracy" and encourages the deployment of military resources, coordination, prosecution, and the implementation of the BMPs. States alone can ensure the contribution of naval assets, the criminalization of piracy within domestic law, and require BMP use on flagged vessels. The CGPCS has no authority to make binding decisions on participants, and this is a challenge for the group. As Hughes explained, "It's not so much a forcing mechanism; it's a peer pressure mechanism."140

The CGPCS can exert influence by praising to specific countries and organizations, or "cheerleading" as Hopkins described it. ${ }^{141}$ Those contributing military and non-military assets are lauded before the group while donors to the trust fund have also been mentioned in communiqués. International agencies have also sometimes found themselves in the limelight; for example, the UNODC's "targeted and well-executed efforts . . . in the region" were highlighted.

Regional actors who are engaged in prosecution have been singled out for positive mention. In the realm of prosecution and incarceration, Kenya, for example, was an early recipient of praise for having "taken the lead in seeking justice for suspected pirates." 142 The CGPCS also applauded the efforts of Seychelles, which became active in prosecution as its economy was adversely affected by piracy. It welcomed "interest" by Tanzania, ${ }^{143}$ which has not yet fully come on board with CGPCS efforts to further prosecution within the region. Later Yemen joined the list of those "bringing pirates to justice." CGPCS communiqués have also welcomed the positive engagement of the TFG and regional authorities in Puntland, Somaliland, and Galmudug.

The CGPCS has also lauded coordination among various actors. It celebrated SHADE as providing "excellent operational coordination," and noted the "interactive partnership between WG1 and the co-chairs of [SHADE]." China's decision to harmonize its military operations with the IRTC patrol coordinated by SHADE in early 2010, for example, was hailed as enhancing efficiency of military assets. ${ }^{144}$ INTERPOL's establishment of a counterpiracy task force and later partnership with EUROPOL to facilitate the exchange of intelligence and information sharing was noted, as was coordination between the IMO and the European Commission.

It has sought to pressure contributions and further efforts in instances where progress seems lagging. For example, it made special note of the need for the TFG and Puntland to "build their capacity to prosecute and imprison persons." This has significantly improved since 2009, although establishing a causal nexus between this outcome and CGPCS pressure is not easily accomplished. In its calls for support of the trust fund, it singled out industry for contributions and asserted that "industry itself must exert efforts to be better protected against pirates, through compliance with industry-agreed [BMPs]. ${ }^{145}$

This is also done at the working group level. In WG5, for example, Maresca noted that "We are also underlining that because hijacking a vessels is a crime there is a general duty for whomever has that information to share it." ${ }^{146}$ Meanwhile, lists were circulated to flag states and industry associations that identified ships that were not implementing preventive measures, including reporting their presence in the highrisk area to MSC-HOA. This action initiated positive steps to encourage the use of BMPs, but it also produced some controversy over the accuracy of the reports. ${ }^{147}$

Stated commitments by countries are included in the communiqués as a means of holding them accountable before the larger group. The signing of the New York Declaration in 2009 by the major flag states of Panama, Liberia, the Bahamas, and the Marshall Islands to require all vessels flying their flags to implement self-protection measures was noted at the third CGPCS plenary and the additional signers at its following session. By the fifth session, the CGPCS noted its concern with "the continued non-compliance by a minority," although it did not name names. 
Given that it lacks a formal mandate, the CGPCS cannot enforce compliance with agreed programs of work. The one powerful tool that it has is shaming and praising-essentially, peer pressure. "Partners come to the table," explained Hughes, "because they want to, not because they are required to do so; they come because it is in their interests; it's a challenge because the contact group cannot require anyone to do anything as a result of the CGPCS and as a result of the working groups. There is not so much formal power, but the conclusions of the group can bring leverage. It is a peer pressure group." ${ }^{148}$ Such a mechanism can work effectively only to the extent that reputation matters and to the extent that participants can be convinced of the merits of pursuing a given course of action. Yet it is important not to overstate the extent to which naming and shaming have generated compliance. For regional states, financial and technical assistance with security and judicial capacity development is also a potential pull.

The lack of compliance mechanisms is one of the most enduring dilemmas of global governance: while stakeholders may be willing to share information, getting states to commit to enforceable agreements is often extremely challenging. Very few international organizations have robust enforcement mechanisms. Even in those organizations with robust enforcement mechanisms the track record of compliance is uneven. ${ }^{149}$ The "naming and shaming" approach adopted by the CGPCS is similar to that used by other UN bodies, as it is a fairly powerful tool with significantly lower barriers to its use than the creation of more robust enforcement mechanisms.

\section{Lessons of the CGPCS}

The CGPCS is a hybrid mechanism that brings together a variety of actors - states, IGOs, NGOs, and industry-to labor on a pragmatic level to produce concrete outcomes in the areas of their concern. This voluntary, informal structure has contributed to the overall success of counter-piracy programs by pursuing a multi-pronged strategy to mitigate and redistribute costs among various stakeholders. Hughes and others have described it as "a model of good practice" in moving an agenda forward. Quite a few interviewees, including UN civil servants themselves, have noted that one positive feature of the CGPCS is that it is not a UN contact group, which allows it to act independently "and do things that a UN contact group would not be able to do in terms of bureaucracy and procedure." 150 Illustrations of how the informal network structure of the CGPCS has enabled it to circumvent constraints inherent in the UN are presented below. However, and as noted above, the overall structure, particularly the leadership, remains state-centric.

Yet "one of the challenges is that it does not have a formal mandate as such. How do you get people move forward together in a consistent way? The plus is also a challenge." ${ }^{151}$ This is a dilemma of global governance more generally, as there is no authority to enforce compliance with collective goals. Even the most robust mechanisms at the disposal of the international community, such as Security Council Chapter VII measures, are often undermined by defection. The CGPCS offers a number of lessons about why global governance initiatives may or may not be successful in filling gaps in a particular issue area.

Issue and Geographical Focus

Of critical importance is the fact that the CGPCS targets a very specific problem-piracy-in a targeted geographic location - the Somali Basin, the Gulf of Aden, and increasingly the Indian Ocean. By limiting the geographic scope of piracy as a problem, the CGPCS has focused its efforts in dealing with very well-defined challenges of this particular high-risk area. By circumscribing the problem of its focus and the geographic area of its manifestation, the group has placed parameters on what is a very complex issue. In doing so, it also circumscribes the number of affected states. Narrowly defining the problem also allows for potential stakeholders to make a direct assessment of the impact of the issue on their national, organizational, or business interests. More diffuse issues facing the globe allow for broader interpretation of the specific impact of the problem, creating a space for greater internal dissent about the scope and outcomes of the issue. 
Actualized Threat with Cross-cutting Impact

The CGPCS also targets a realized threat to the national interests of a broad range of countries. Unlike climate change, the potentially irreversible effects of which have yet to be realized, or malaria, which is concentrated in the developing world, the costs of piracy are born in the present and adversely affect developed and developing countries alike. Thus while piracy threatens Europe's energy security and exacts costs on the shipping industry in advanced industrial states, it also adversely affects regional states such as Kenya, Mauritius, Seychelles, and Yemen whose economies have experienced downturn. It also affects countries with large numbers of seafarers, such as India, Pakistan, and the Philippines.

Unlike a communicable disease, the issue does not need to be addressed by all states to eradicate it. Piracy presents a different type of collective action problem. Competing powers, such as India and Pakistan (which was welcomed on board in June 2010) and Greece and Turkey have a convergence of interest in countering piracy. Thus one crucial factor that makes this arrangement effective is that countervailing state interests that might otherwise inhibit the emergence of a response mechanism are largely absent. The five permanent members of the Security Council, which are oftentimes divided on such issues as humanitarian intervention, agree that piracy is antithetical to their national interests.

As Swarttouw explained the group's "unity of purpose" is a key ingredient to its success. "You couldn't deal this way with the Middle East peace process, let's say. It's contained ... and there is no one in the world who is in favor of piracy! There is no one who is in favor of climate change, but not everyone agrees on climate change. On piracy basically everyone agrees." 152

Like-minded Coalition of the Willing to Lead

Major powers have incentives to provide international and regional public goods. As Barrett notes, "Their leadership is not always sufficient, but it is almost always necessary." 153 Having the United States take the lead at the outset and provide resources to back up its commitment, undoubtedly contributed to the CGPCS's emergence and continuation. Yet as Hopkins has noted, piracy is not a national security threat to the United States. The consolidation of a like-minded coalition of the willing has been a key to the CGPCS's relative success.

As Winkler explained: "The downside to the whole set up is that it is dependent on a number of active states. Because it is not a UN contact group, the UN bodies are there but they are not running it ... you are dependent on a number of states not only taking on the chairmanship but of actually doing something. I have spent a lot of my own time and resources; I also have three or four staff of my legal service here working on counter piracy." ${ }^{154}$ At the December 2012 plenary session, the United States volunteered to take on the newly implemented one-year long chairmanship but noted that it had done so by default. Yet because the CGPCS does not have a mechanism to offset the costs of chairmanship at the plenary or working group level, it undoubtedly makes it difficult for countries that are less resourced to take on the job, which is very costly in terms of time and money.

Non-state Actors, Part of the Solution

Given the primarily legal and military-based approach to the problem of piracy, it is unsurprising that states and state-based organizations remain the overwhelmingly dominant actors in the contact group. Non-state actors, while included early on in the workings of the GCPCS, have only just begun to have more of a voice and in some areas remain marginalized.

Industry was invited to participate in WG3 from the outset by its initial US civilian co-chair, MARAD. MARAD's Owen Doherty emphatically stated, "We could not have done what we did without industry." 155 Despite industry engagement at the working group level, it is only in the past year that it has acquired a seat at the plenary 
sessions, having previously been limited to attending as part of a national delegation. The process of inclusion has been gradual and contentious. ICS secretary-general Hinchliffe recalled: "In the early days, we certainly were marginalized and were made to feel by some governments, but not all, that our views were not of any interest to the governments in the contact group, and I think that was a shame ... but that has evolved now, and ... there seems to be more of a will to listen to an industry intervention." 156 While the CGPCS has become more inclusive, Hinchliffe still senses a "countercurrent," particularly among those governments that do not have a relationship with industry, although only from a minority of states actors that are located in the region. Hinchliffe continues, "I would like to see growth in the influence of industry; there is still room for improvement in that."157 The ICS was not the only non-state actor to note that industry should have more involvement in the CGPCS's output. One NGO leader went as far as to suggest that industry should be allowed to co-chair working groups in areas of its concern. ${ }^{158}$

While NGOs are crucial actors in today's global governance efforts, they are typically marginalized in issue areas that fall under the domain of international peace and security. In this regard, the CGPCS is unusual because of its incorporation of NGOs as observers, collaborators, and to some degree active participants in CGPCS activities. The predominant NGOs involved in the CGPCS are NGOs focused on seafarer welfare including the Seamen's Church Institute and Maritime Piracy Humanitarian Response Programme (MPHRP). Their mark on the CGPCS's work has become more apparent within the past year or so as communiqués have increasingly drawn attention to the plight of seafarers who have experienced pirate attacks, particularly those who have been held hostage for months at a time. SCl president and executive director Rider noted that attention to the issue of seafarer welfare is evidence that the voice of NGOs such as SCl is not only being heard within the CGPCS but that their input has also influenced the group's work. ${ }^{159}$ In addition to the work of welfare-focused NGOs, the NGO sector is also represented by Oceans Beyond Piracy, whose mandate focuses on supporting effective sustainable responses to piracy. In July 2012, OBP was invited to present to the twelfth plenary session, which the meeting communiqué argued "proves the importance that the CGPCS attributes to the role of non-state actors in countering piracy." 160 NGO attendance in CGPCS activities and working group meetings, however, remains carefully controlled.

Other types of non-state actors have also been brought to provide special expertise on particular issues. A private armed security company, for example, was invited to discuss the issue of armed guards aboard ships. Academics have also provided input at the working-group level.

Bringing in the UN

Under the Republic of Korea's chairmanship, it was noted that "the CGPCS strongly believed that coordination and cooperation among the contact group participants and the UN is a critical factor for the continued success and effectiveness of the contact group." ${ }^{161}$ While the CGPCS lacks formal standing, it has harnessed the resources of formal established bodies, especially the authority of the UN Security Council and the IMO, the institutional resources of the UN Secretariat, UNDPA and UNOLA, and the moral force of the UN secretarygeneral. By embedding UN agencies into the working groups, UNODC for legal issues, the IMO on best practices, UNPOS for communications, it has in effect acquired implementation capacity, efforts enhanced by its trust fund which supports initiatives by these UN agencies.

The CGPCS's development, however, has not been without contention. Some UN organizations were turf conscious. As one interviewee explained: "In the past, there had been rivalry between counter-piracy people and the people working on Somalia. We had a sense of urgency because we had to protect our seafarers and our ships. So we have moved very quickly on issues where people on Somalia have been working on something for ten years and little has happened. Then suddenly the counter-piracy people come in with a lot of money, because of the public interest in piracy off the coast of Somalia. Suddenly you build a prison there, [and they ask], 'How does this fit into our project of traditional capacity building in Somalia?' I think it is much less now. And the cooperation between all these UN agencies in Nairobi has improved a lot." 162 
Yet another interviewee noted that the IMO was skeptical about the role of the CGPCS, and particularly WG3, engaging on issues within its remit. Speaking from the perspective of industry, Hinchliffe noted:

One of the reasons for the ICS existing is to represent industry at the IMO . . . we were always slightly nervous, and we were very open about this with the US Maritime Administration when the initial discussion was going on . . . because it was very important to make sure ... that it should at no time be to the detriment to the International Maritime Organization. So there's always been this slight tight rope feeling to the work in Working Group 3. And because of the lack of Terms of Reference for the contact group it's always meant that anything that Working Group 3 did and passed on to plenary had to be done with a very clear indication of what it was intended the plenary should do. Either send the work to the IMO if it was something that needed to be endorsed or enacted in some way, or if there was going to be discussion about an impact on regulation, then it had to go to the IMO. If it was more for the plenary to note, it was fine to remain in the contact group. ${ }^{163}$

He further noted that "there is this sensitivity between Working Group 3 and the IMO, [but] I think that relationship has evolved. I think the IMO has become more engaged in the CGPCS discussion over time." 164 Hopkins would concur: "the IMO has since become a very, very strong partner and collaborator; and we sorted out our different lanes of operation, and nothing that the contact group does is at odds with the IMO's authority or activities or interests . . but it took a while for the IMO to understand that."165

Flexibility

Without terms of reference, the arrangement is flexible and thus adaptable and able to produce responses quickly. As Ambassador Hayong Moon asserted, "This informality enables the CGPCS to work efficiently and practically because it is easy for the CGPCS to adapt itself ... . in response to the developments in the Somalia piracy issue." 166

The lack of terms of reference has allowed participants within the group to creatively navigate norms of sovereignty in order to achieve pragmatic results. Standard diplomatic procedures would dictate that the TFG (as of August 2012 the Federal Government of Somalia would be the sole representative of the country. While de jure recognition as the legitimate government of the Somalia by the international community, sovereignty is in practice divided among four authorities: the Federal Government of Somalia, Galmudug, Puntland, and Somaliland. The CGPCS's flexibility allows the active participation of these Somali stakeholders in the form of the Kampala Process, also formally known as the Somali Contact Group on Counter-Piracy for which the UNPOS serves as a secretariat. Indeed, practical needs to have sub-state actors involved in tackling piracy within their respective territorial strongholds trumped standard diplomatic procedures and the CGPCS's flexible nature and working groups helped to facilitate this. In essence, while UN Security Council documents as well as CGPCS communiqués strongly affirm respect for Somalia's sovereignty, needs on the ground (and sea) required the active participation in a diplomatic setting of regional authorities.

As Swarttouw asserted, this informal arrangement of diverse actors "would never have worked in a formal setting." "As an experienced diplomat," he further asserted, "it was a great pleasure to work in this setting; it was just so easy to get things done." 167

Flexibility has also been used to further the inclusion of other non-state actors. Salicath recalled during Norway's chairmanship: "One country had protested against allowing industry represented in the room and that became a major problem. So we concluded that they were members of their national delegations. If we had rules of procedure, we would have had endless discussions and spent time on that day in and day out, and at least one or maybe several countries would have made us do nothing ... Sometimes it's better not to have rules of procedure because they are misused easily by some. Within the CGPCS, cooperation with industry is indispensable, and without it we would have accomplished much less." 168 
The CGPCS aims to provide guidance but not authoritative directives. Efforts have thus been directed on technical, legal aspects, and practical implementation. Although piracy, as Somsen explained "is not really a political issue since everyone is against it ... when it comes to issues [such as] the freedom of passage of a warship you have some of these 'reflexes' that [make] it a political issue for other reasons other than for piracy. Sometimes these issues filter in and out of discussions within the contact group." 169

Yet as Swarttouw explained, "[We] agree to disagree, that is where many of these international organizations get stuck on one or another issue. Be pragmatic. We didn't have to agree because the contact group is not setting rules or directives for participating states." ${ }^{170}$

\section{Challenges for the CGPCS}

While CGPCS participants have made considerable progress in generating coordination and cooperation on anti-piracy efforts, the contact group's work is not seamless. This section highlights four key challenges that the CGPCS now faces: resources, sustainability, equitable partnership, and strategic vision.

A significant issue of global governance is generating the resources necessary to undertake voluntary collective initiatives. Given the magnitude of the challenges it faces regarding regional capacity building, the CGCPS trust fund is woefully underfunded. Complicating matters is the fact that there is disagreement as to which actors are responsible for contributing more. Some states find that industry should contribute more, while some industry voices have noted that it is the responsibility of states to take care of the problem. Industry, noted one interviewee, has already incurred significant costs as a result of this problem and therefore does not "think it's appropriate for us to make a contribution ... to the trust fund . . . although individual companies have been happy to do so." ${ }^{171}$ Meanwhile, state officials argue that this is an excuse as much of the cost of piracy is passed on to consumers. At the same time, piracy is not at the top of many national agendas, which means that funding for counter-piracy programs is not a top priority for many governments involved. "The biggest impediment," Hopkins notes, is that "it is seen as a nuisance rather than a threat." ${ }^{172}$ Yet if capacity building in effect is the GCPCS's answer to piracy, then clearly significantly more resources will have to be devoted to efforts on the ground.

Undoubtedly gains gave been made in stabilizing Somali waters and beyond. At the same time, however, the International Piracy Ransoms Task Force expressed concern that this trend was "fragile and reversible." ${ }^{173}$ Owing to its military and judicial approach to the problem, which amounts to altering the risk of undertaking maritime crime without being able to reduce the potential pay-off, it is likely that counter-piracy activities will remain costly to maintain. It is not only the ransoms task force that has expressed concerns about the viability of current initiatives. One government official noted that the declining enthusiasm for anti-piracy efforts was reflected in the way in which GCPCS plenary sessions were becoming routinized and lacking in fresh ideas. ${ }^{174}$ As his working group is just now picking up steam, Maresca further elucidates this issue:

The major obstacle is, of course, obtaining an increased coordination and collaboration among countries ... and having close coordination means spending a lot of effort, time, and resources to make this coordination work. ... With the number of successful attacks declining, the willingness of governments to improve coordination is decreasing. It's good that the number of crew taken is decreasing but it is reducing the pressure on governments to get together. . . The military has the same concern; they are concerned that the financial support to their operations will decrease. ${ }^{175}$

In addition to lacking adequate resources and existing under a shadow of uncertain sustained commitment among participants, the CGPCS must also confront limitations to its working methods, particularly regarding agenda setting and decision making which at present are ad hoc and opaque. Such a finding is consistent with David Guilfoyle's analysis of the CGPCS as a transnational governance network, which he notes generally can be "non-transparent and technocratic." 176 While inclusive of diverse countries, in reality the CGPCS appears to be driven by a core group. Precisely which states constitute the "core group" remains unclear, although it 
is undoubtedly comprised of key western countries found in the circle of those that convened the first CGPCS plenary meeting as well as those chairing the working groups or having chaired plenary meetings. In terms of driving action forward, there are obvious benefits to a tight-knit group of like-minded actors as cohesion facilitates a convergence of interests and thus consensus on the CGPCS agenda and strategy, which are essentially hammered out among the core group on the eve of the plenary sessions. Chairing countries, which produce the initial draft communiqués often drawing on preceding ones as a template, however, also have the opportunity to provide input.

The proverbial flip side of the coin of sidestepping dissent is that concentrated agenda and decision-making power among the few may create disincentives on the part of those who are excluded but whose cooperation is necessary to sustainably counter piracy. Somsen noted that there indeed "could be more participation from regional governments." Speaking frankly, she asserted that there are an "overwhelming number of western countries at the table" with a western focus, although uneven participation "also relates to regional capacity and other priorities from those countries ... Maybe because a lot of the things we discuss may not be of direct interest to persons in the region ... . and when it comes to capacity building it's not a big deal ... the focus is too much on issues not of their direct concern."

In this regard, efforts to address the concerns of Somalia itself as well as to foster more equitable participation among willing CGPCS actors may be necessary to further advance the common denominator goal-countering piracy in a sustainable manner. Somsen further elaborated that

[there is] room for the contact group to look into those subjects that are of direct interest to Somalia itself so that there is also a strong willingness on the side of Somalis to tackle that and to see how we can do that together. I think there is a strong interest in maritime security and the Exclusive Economic Zone ... and [we should] have a bit more focus on those issues as well. Some issues are of clear-cut importance for shipping countries-open seas and easy access to harbors-and other issues relate much more to Somalia itself.

Hence, efforts at "finding common ground with Somalis themselves" are crucial to move collective efforts forward. ${ }^{177}$ More specifically, OBP's Jon Huggins noted the need to address Somali concerns with securing the country's maritime resources, which CGPCS leading states have been reluctant to do from the outset. Moon echoed these concerns: "If I should find the weaknesses of the CGPCS, I may suggest that the CGPCS needs stronger and closer relationship and communication with the Somali government and the regional states. So far, the active participants of the CGPCS are governments and industries that are vulnerable to piracy. However, from the year of 2014, the CGPCS is planning new initiatives to engage states in the Horn of Africa." ${ }^{178}$

Moreover, in 2012, the Trust Fund provided resources to the Kampala Process in order to develop a Somali Maritime Resource and Security Strategy under the facilitation of UNPOS, UNODC, the IMO and FAO. ${ }^{179}$ This indicates a shift in the direction toward more inclusion of Somali viewpoints and concerns.

On the issue of addressing power imbalances among governments within the CGPCS, Somsen noted that "it is also a matter of comfort sometimes." Some countries have "different ways of operating;" it is "definitely a lesson learned if you want to have a mechanism like this work for the whole world. These cultural differences should be taken into account, and we should have a bit more patience with some other countries that also matter to the subject." 180

Participation at the working group level itself, moreover, can be limited, as resource-challenged countries cannot afford to send delegations from their home countries to meetings in London, New York, and Washington, D.C. Maresca has registered some changes within WG5: "We started to work without regional participants and little by little we have been adding pieces here and there. Seychelles is a regularly contributing member, and 
Mauritius and Tanzania, for example, were present at the group's last meeting in Rome. Little by little we hope to have an increasing participation." 181 WG1's Hughes similarly explained the importance to "do it with regional partners; not to them." 182 In this regard, the 2013 working group meetings in Addis Ababa were a step forward in engaging the region.

The CGPCS was intentionally constructed as a flexible, impermanent structure. As a part of this mechanism, the CGPCS from the beginning focused on developing responses with immediate impact to quickly contain the situation rather than developing a long-term strategy. Questions of collective vision, formal evaluation, and structures for maintaining institutional memory were not addressed. As the successes of this approach become apparent, the CGPCS has the opportunity to speak to a wider international audience interested in learning lessons gleaned from its operations, but has until now lacked formal structures for review and the development of lessons learned. The issue of institutionalized memory is particularly important, as individuals drift in and out of the CGPCS as their national and international posts bring them to other departments and parts of the globe.

There are diverging opinions coming to the surface on what is at stake in the region. For some, suppression is enough to achieve the goal of securing trade routes; others have a more holistic view of the depth of engagement necessary to stabilize Somalia, which has long been deemed the ultimate solution to "the scourge." A multi-faceted approach requires robust attention also to development, humanitarian, and governance issues and generous resources to back up commitments.

In a concept note addressed to the secretary-general in late 2012, India's permanent representative asserted that "there is a general recognition in the Security Council that the problem of maritime piracy and armed robbery at sea cannot be tackled by military means alone; the problems on shore, ranging from underdevelopment and poverty to the presence of financers and kingpins, also need to be addressed in a comprehensive and holistic manner." ${ }^{183}$

Singhal noted that initially the CGPCS has "gone outside of Somalia (for example, prosecuting pirates in the region, coordinating naval forces) for a response due to a lack of credible governance structures in Somalia. Now that the transition has ended in Somalia, the CGPCS can put the responsibility back inside Somalia by helping to build the rule of law and livelihood opportunities ashore. How do we stop pirates from coming to the sea? The CGPCS had focused on containment. Now it has to move one step beyond and ensure that they will not leave Somalia in the first place. Now is the time to think in this direction. Otherwise, this will be a process without an exit mechanism." 184

\section{Lessons for Global Governance}

Our analysis suggests that the CGPCS has made progress in filling governance gaps despite its lack of authority and resources. The CGPCS's strengths and weaknesses are inherent in its structure. While a common denominator exists among participants, this does not mean that there are not underlying interests that sometimes complicate collective efforts. The group's flexibility, however, facilitates navigating interests and national sensitivities that might otherwise stymie efforts.

A key feature of the CGPCS is its lack of formal procedure and standing secretariat, which renders it a highly agile mechanism. This informal structure is similar to other initiatives found in the arena of global governance. An apt comparison can be made with the Proliferation Security Initiative, a trans-governmental initiative designed to support counter-proliferation activities focused on weapons of mass destruction (WMD) that was launched by the United States in 2003. Indeed the CGPCS's founding states consciously drew on this model. In pursuing its core aim to interdict WMD-related materials, the security initiative takes a similar informal and solution-focused approach to encouraging intergovernmental cooperation. ${ }^{185}$ However, unlike the CGPCS it has encountered opposition from key states on this issue area, including such powers as China and India. ${ }^{186}$ 
Without terms of reference, barriers to entry by states into the CGPCS are very low. Moreover, the nonbinding nature of participation in the CGPCS means that there is less potential for home-state politics to constrain participating representatives, although it does mean that the CGPCS lacks the authority to enforce decisions in its own right. One way that the CGPCS has been able to mitigate this shortfall is to work with and through UN bodies and agencies.

As discussed above, sustainability is a challenge as the informal nature of participation makes it relatively easy for the CGPCS's forward motion to wane, as states shift their attention to other issues and problems. One tradeoff of the voluntary structure is that in the absence of more formal institutionalization, the CGPCS's work can ebb and flow with changes in domestic political pressures.

The CGPCS's decision-making process, which proceeds on a presumption of consensus in the absence of formal objections, can be easily abused by participants with interest in avoiding specific decisions. This can be documented in other organizations: in withdrawing from the network-structured Kimberley Process (KP), the international NGO Global Witness specifically cited the abuse of the KP's consensus-based decision-making process as a reason for what they perceived to be failures of this system, arguing that "consensus decisionmaking means that one participant can block progress on key issues. The KP has been unable to take strong decisions to crack down on cases of serious non-compliance. This inability to hold members to account for rules of the scheme undermines its effectiveness and its credibility in the eyes of consumers and participants." 187 The CGPCS appears to have elided this issue with its narrow focus, which draws together actors with a clear selfinterest in actually solving the problem.

One inherent characteristic of informal collective-decision making mechanisms is the significance of backchannel discussion and influence. The CGPCS does not appear to have escaped this problem: the dominance of a small group of participants in the CGPCS is a reflection of highly asymmetric influence. However, the practical impact of this imbalance appears has not thwarted collective action. This is likely due to the limited issue space: as discussed above, participants share a genuine interest in solving the problem of piracy.

In the context of the challenges and successes of other global networks, the CGPCS suggests that this particular model can be effective when the issue focus can be defined narrowly, when stakeholders have a self-interest in solving the problem and can be identified and encouraged to participate, and when there are no countervailing political pressures or issues linkages that would encourage any powerful stakeholders to act as spoilers. In addition, the voluntary nature of CGPCS activities and the relatively anemic donations to the trust fund suggest that this structure is most valuable when it serves to identify specific tasks that stakeholders can accomplish within their governments or organizations, such as sharing information, coordinating national laws, and engaging in specific military or humanitarian operations using national resources. It may be less successful in circumstances in which voluntary collective contributions to some external group or funds are necessary.

\section{Conclusion}

Once thought to be a threat without contemporary significance, piracy has emerged as a significant challenge to states, industry, and seafarers' welfare organizations alike. According the letter of the permanent representative to India to the UN secretary-general, pirate attacks in 2012 remained "alarmingly high." 188 Currently Somali pirates are still holding more than 100 seafarers hostage. For them and their families and communities, the brutal realities of piracy are ongoing. Meanwhile, ordinary Somalis suffer as pirate gangs disrupt local communities, including with the socially disruptive practices they often bring along with them such as prostitution and drug and alcohol consumption, which may have played a role in mobilizing opposition to piracy in Somalia.

One discernible accomplishment of the contact group is its fostering of an anti-piracy community focused on East Africa that has steadily expanded since the CGPCS's inception in early 2009. Indeed, the number of 
state participants has almost trebled to 62 . The participants assume shared responsibility to contribute to the collective effort, many working closely in multiple multilateral fora and with key UN partners on the ground in the region. Although the weight of responsibility among various actors is sometimes contentious, particularly between governments and industry, there is a generalized consensus that anti-piracy requires efforts from all stakeholders.

Dutch Ambassador Henk Swarttouw describes the CGPCS mechanism as "multilateralism light," the merits of which "are achieving tangible results and excellent coordination and cooperation at very limited costs, no budget, no secretariat and no bureaucracy, yet able to focus on getting the job done." ${ }^{189}$ In this regard, the CGPCS can serve as a model for future collective efforts, particularly to address issues where there are no significant countervailing interests.

Within the realm of counter piracy, there may be spillover effects to other troubled regions such as West Africa's Gulf of Guinea. Certainly regular face-to-face interaction at plenary meetings, in the working groups, and in the fora of partner organizations such as the IMO has fostered a robust interpersonal anti-piracy network within which knowledge and expertise flows and could be applied elsewhere on the globe. The CGPCS, which provided political support to SHADE, may have positive spillover for international relations beyond counter-piracy. One interviewee rhetorically asked, "Where in the world would Chinese, Russian, and NATO ships be working alongside each other? By the military, this opportunity has been seized to indeed work on bilateral contacts that have been on the high seas in the operational area; there have been lots of visits by Chinese officers to NATO ships and the other way around." 190

At the start of 2013, observers were hopeful that a "new dawn" was emerging in Somalia, as the TFG gained control over areas once dominated by Al Shabab and the new Federal Government created in August 2012 was gaining increasing international recognition. Although it remains uncertain whether the sun is indeed on the horizon for war-torn Somalia, one thing is beyond doubt: without the sustained, concerted efforts of the international community to combat piracy, bolster the federal government, and fuel socioeconomic development new light will not break.

For now, participants remain vested in the CGPCS's work. "Someone has to ensure that the implementation is still going on," asserted Ambassador Winkler, "Someone has to maintain the pressure. I would be worried that if the CG disappeared, I would worry that progress would disappear." 191 


\begin{tabular}{ll} 
Appendix I & \\
List of CGPCS Plenary Chairs & \\
Plenary Session & Country Chair \\
January 2009 & United States \\
March 2009 & Egypt \\
May 2009 & United States \\
September 2009 & Japan \\
January 2010 & Norway \\
June 2010 & Greece \\
November 2010 & Republic of Korea \\
March 2011 & Turkey \\
July 2011 & Singapore \\
November 2011 & The Netherlands \\
March 2012 & United Arab Emirates \\
July 2012 & Spain \\
December 2012 & India \\
May 2013 & United States \\
\hline
\end{tabular}




\section{Appendix 2}

\section{Methodological Note}

This research is significantly based on an analysis of CGPCS, UN Security Council, and IMO documents as well as interviews with 25 individuals who are participants in the contact group. In total, some 60 individuals were contacted for interviews. Of participating actors, eighteen were government officials, two were from UN bodies, and five were non-state actors. These individuals were identified from CGPCS participants as well as the December 2012 plenary list of attendees. The researchers would like to express their profound gratitude for those who participated in this study. They also acknowledge that the sample of interviewees does not reflect the diversity of state actors that participate in the CGPCS, although bias is likely indicative of the contact group's configuration. 
Notes

1 UN Security Council resolution 1851, December 16, 2008.

2 ICC International Maritime Bureau, "Piracy and Armed Robbery Against Ships: Annual Report 1 January -31 December 2008," London, United Kingdom, January 2009.

3 UN Security Council resolution 1816, June 2, 2008.

4 ICC International Maritime Bureau, "Piracy and Armed Robbery Against Ships: Annual Report 1 January -31 December 2009, , London, United Kingdom, January 2010

5 ICC International Maritime Bureau, "Piracy and Armed Robbery Against Ships: Annual Report 1 January -31 December 2010," London, United Kingdom, January 2011.

6 Jeffrey Gettleman, “The Pirates are Winning!” New York Review of Books, September 14, 2010.

7 Information about attacks and hostages are taken from the annual reports of the IMB Piracy Reporting Centre

8 Anna Bowden, The Economic Cost of Maritime Piracy (Louisville, Colo.: One Earth Future Foundation [OEF], 2010).

9 Anna Bowden and Shikha Basnet, The Economic Cost of Maritime Piracy, 2011 (Broomfield, Colo.: OEF, 2012), available at: http://oceansbeyondpiracy.org/sites/default/files/economic cost_of_piracy 2011.pdf.

10 Final Report of the International Piracy Ransoms Task Force, December 11, 2012, available at: http://www.fco.gov.uk/ resources/en/pdf/publications/final-report-international-piracy-ransoms-task-force.

11 John Norris and Bronwyn Bruton, "Twenty Years of Collapse and Counting: The Cost of Failure in Somalia," A Joint Report of the American Center for Progress and the One Earth Future Foundation, September 14, 2011, available at: http://www. americanprogress.org/wp-content/uploads/issues/2011/09/pdf/somalia.pdf.

12 Bowden and Basnet, The Economic Cost. In 2012, this figure amounted to an estimated \$6 billion. See Jonathan Bellish, The Economic Cost of Somali Piracy 2012 (Broomfield, Colo.: OEF, 2013).

13 Data and image are from Bellish The Economic Cost of Somali Piracy 2012

14 Numbers are from Kaija Hurlburt and Cyrus Moody, The Human Cost of Somali Piracy 2011 (Broomfield, Colo.: International Maritime Bureau and One Earth Future Foundation, June 2012).

15 EU NAVFOR, "Mission," available at: http://eunavfor.eu/mission (accessed April 6, 2013). More precisely, the website notes the longest duration as 1001 days, approximately two years and eight months.

16 Hurlburt and Moody, The Human Cost, 7.

17 Data is taken from ICC International Maritime Bureau annual reports on piracy and armed robbery against ships for the years of 2005-2012.

18 Interview with Donna Hopkins, Coordinator, Counter Piracy and Maritime Security, Bureau of Political-Military Affairs, US Department of State, November 8, 2012.

19 UN Development Programme (UNDP) Somalia, Somalia Human Development Report 2012: Empowering Youth for Peace and Development (Nairobi: UNDP Somalia, 2012), available at: http://www.so.undp.org/shdr/Somalia\%20Human\%20 Development\%20Report\%202012.pdf.

20 World Bank, The Pirates of Somalia: Ending the Threat Rebuilding the Nation (Washington, DC: World Bank, 2013).

21 UNODC, The Globalization of Crime: A Transnational Organized Crime Threat Assessment (Vienna: UNODC, 2010), “Maritime Piracy," available at: http://www.unodc.org/documents/data-and-analysis/tocta/9.Maritime_piracy.pdf

22 World Bank, The Pirates of Somalia, 112-117.

23 Tristan McConnell, "Pirate Wars," GlobalPost, March 16, 2012, available at: http://www.globalpost.com/dispatch/news/ regions/africa/120306/pirates-Somalia-how-it-started\%20 (accessed April 6, 2013).

24 Quoted in Geiß and Petrig, Piracy and Armed Robbery at Sea, 9.

25 Stig Jarle Hansen, Piracy in the Greater Gulf of Aden: Myths, Misconceptions and Remedies (Oslo, Norway: Norwegian Institute for Urban and Regional Research, October 2009), 8.

26 Ibid., 27.

27 Robert Haywood and Roberta Spivak, Maritime Piracy (Oxford: Routledge, 2012), 13.

28 "Report of the Secretary-General pursuant to Security Council Resolution 1846 (2008)," S/2009/146, March $16,2009$.

29 World Bank, The Pirates of Somalia (ref: note 20)

30 Quoted in Thomas G. Weiss, Can the World Be Governed? (Cambridge: Polity, forthcoming). Kishore Mahbubani, The Great Convergence: Asia, The West, and the Logic of One World (New York: Public Affairs, 2013), 3. 
31 Thomas G. Weiss and Ramesh Thakur, Global Governance and the UN: An Unfinished Journey (Bloomington: Indiana University Press, 2010). Weiss and Thakur's model includes: knowledge, norms, policies, institutions, and compliance.

32 Interview with Peter Hinchliffe, Secretary-General, International Chamber of Shipping, January 7, 2013.

33 Interview with Thomas Winkler, Ambassador and Legal Adviser, Danish Ministry of Foreign Affairs, December 5, 2012.

34 Geiß and Petrig, Piracy and Armed Robbery at Sea, 11-12.

35 Ibid., 54

36 Robert Haywood and Roberta Spivak, Maritime Piracy (London: Routledge, 2012,), 96.

37 Geiß and Petrig, Piracy and Armed Robbery at Sea, 137.

38 Robert Haywood and Roberta Spivak, Maritime Piracy (London: Routledge, 2012,), 62

39 Interview with Peter Hinchliffe, January 7, 2013.

40 These are: Comoros, Egypt, Eritrea, Jordan, Mauritius, Mozambique, Oman, Saudi Arabia, South Africa, Sudan, and the UAE. France is eligible to sign but has not done so as of April 2013.

41 "Report of the Special Adviser to the Secretary-General on Legal Issues Related to Piracy off the Coast of Somalia," Security Council document S/2011/30, January 25, 2011, 13.

42 Interview with Thomas Winkler, December 5, 2012.

43 Interview with Carl P. Salicath, Senior Adviser, Royal Norwegian Ministry of Foreign Affairs, December 8, 2012.

44 Un-attributable interview, January 2013.

45 "Report of the Secretary-General Pursuant to Security Council Resolution 1846 (2008)," S/2009/146, March 16, 2009.

46 Interview with Chris Holtby, Ambassador of the United Kingdom to the Republic of Estonia, January $28,2013$.

47 Scott Barrett, Why Cooperate? The Incentive to Supply Global Public Goods (Oxford: Oxford University Press, 2007).

48 Un-attributable interview, January 2013.

49 Secretary of State Condoleezza Rice, "Combating the Scourge of Piracy," New York, NY, December 18, 2006, available at: http://2001-2009.state.gov/secretary/rm/2008/12/113269.htm.

50 UN General Assembly, "Oceans and the Law of the Sea," A/RES/59/24, February 4, 2005, available at: http:// oceansbeyondpiracy.org/sites/default/files/un general assembly resolution 59-24.pdf.

51 IMO Maritime Safety Committee (MSC) Circ. 622 and MSC Circ. 623, May 1993. These were updated in 1999 and updated in 2009. Kraska, Contemporary Maritime Piracy, 65-6.

52 http://www.imo.org/blast/blastDataHelper.asp?data id=25332\&filename=A1002(25).pdf

53 “Piracy and Armed Robbery against Ships," IMO A 25/Res. 1002, December 6, 2007, available at: http://www.imo.org/blast/ blastDataHelper.asp?data_id=25332\&filename=A1002(25).pdf.

54 IMO Briefing 47, November 29, 2007, available at: http://www.imo.org/blast/mainframe.asp?topic id=1472\&doc id=8751 (accessed March 4, 2013).

55 Geiß and Petrig, Piracy and Armed Robbery at Sea.

56 UN Security Council resolution 1816, June 2, 2008.

57 James Kraska, Contemporary Maritime Piracy: International Law, Strategy, and Diplomacy at Sea (Santa Barbara, Calif.: Praeger, 2011), 156

58 Ibid., 149.

59 Ibid., 155.

60 Memorandum from the President, Maritime Security (Piracy) Policy, June 14, 2007, available at: http://georgewbushwhitehouse.archives.gov/news/releases/2007/06/20070614-3.html (accessed April 6, 2013).

61 UN Security Council resolution 1851, December 16, 2008.

62 Secretary of State Condoleezza Rice, "Combating the Scourge of Piracy," New York, NY, December 18, 2006, available at: http://2001-2009.state.gov/secretary/rm/2008/12/113269.htm.

63 National Strategy for Maritime Security, September 2005, available at: http://georgewbush-whitehouse.archives.gov/ homeland/maritime-security.html\#intro.

64 Ibid.

65 Memorandum from the President, Maritime Security (Piracy Policy), June 14, 2007, available at: http://georgewbushwhitehouse.archives.gov/news/releases/2007/06/20070614-3.html (accessed March 4, 2013).

66 Interview with Donna Hopkins, November 8, 2012.

67 Interview with Donna Hopkins, November 8, 2012. 
68 Interview with Federico Torres Muro, Ambassador, Ministerio de Asuntos Exteriores y de Cooperación, Spain, January 21, 2013.

69 Email correspondence with Hayong Moon (via Jiyoung Kim), Ambassador, Ministry of Foreign Affairs, Republic of Korea, April 4, 2013.

70 Interview with Donna Hopkins, November 8, 2012.

71 Interview with Thomas Winkler, December 5, 2012.

72 CGPCS, First Plenary Session Communiqué, January 14, 2009.

73 CGPCS, First Plenary Session Communiqué, January 14, 2009.

74 Interview with Donna Hopkins, November 8, 2012.

75 Memorandum from the President, Maritime Security (Piracy) Policy, June 14, 2007, available at: http://georgewbushwhitehouse.archives.gov/news/releases/2007/06/20070614-3.html (accessed April 6, 2013).

76 Interview with Donna Hopkins, November 8, 2012.

77 Interview with Donna Hopkins, November 8, 2012.

78 Interview with Thomas Winkler, December 5, 2012.

79 Interview with Thomas Winkler, December 5, 2012.

80 Interview with Hester Somsen, Head of Unit, Crisis Management and Peacekeeping Operations, Security Policy Department, Ministry of Foreign Affairs, Netherlands, February 13, 2013.

81 Interview with James Hughes, Deputy Head, Global Security Issues, Security Policy Department, Foreign Commonwealth Office, United Kingdom, February 22, 2013.

82 Interview with Chris Holtby, January 28, 2013.

83 Interview with Chris Holtby, January 28, 2013.

84 Interview with Donna Hopkins, November 8, 2012.

85 CGPCS, "Chair's Conclusions," Meeting of Working Group 1 on Operational Coordination and Information Sharing and Establishment of a Potential Regional Coordination Centre," London February 24-25, 2009.

86 WG1 Contact Group on Piracy off the Coast of Somalia, Regional Capability Development Needs Assessment and Prioritisation Mission to East Africa and Gulf of Aden 27 April -15 May 2009, Initial Post-visit Report," presented at Informal Meeting of CGPCS Working Group 1, Seoul, 10 June 2009, Regional Capability Development.

90 Interview with Alan Cole, Regional Coordinator, Counter-Piracy Programme, UNODC, January 28, 2013.

91 CGPCS Working Group on Legal Issues, "Chairman's Conclusions," Fourth Meeting of Working Group 2, November 2009.

92 CGPCS, Sixth Plenary Session Communiqué, June 10, 2010.

93 "Report of the Secretary-General on possible options to further the aim of prosecuting and imprisoning persons responsible for acts of piracy and armed robbery at sea off the coast of Somalia, including, in particular, options for creating special domestic chambers with international components, a regional tribunal or an international tribunal and corresponding imprisonment arrangements, taking into account of the work of the Contact Group on Piracy off the Coast of Somalia, the existing practice in establishing international tribunals, and the time and resources necessary to achieve and sustain substantive results," S/2010/394, July 26, 2010.

94 Ibid.

95 France Diplomatie, "Maritime Piracy," available at: http://www.diplomatie.gouv.fr/en/french-foreign-policy-1/defencesecurity/organized-criminality/maritime-piracy/article/somalia-report-by-jack-lang-on (accessed April 7, 2013).

96 Xan Rice, "Somali Pirates Should Face Special Courts, Says UN Envoy," Guardian, January 26, 2011, available at: http://www. guardian.co.uk/world/2011/jan/26/somali-pirates-jack-lang-report.

97 Interview with Alan Cole, January 28, 2013.

98 Interview with Thomas Winkler, December 5, 2012.

99 Interview with Alan Cole, January 28, 2013.

100 Interview with Peter Hinchliffe, January 7, 2013.

101 CGPCS, Fourth Plenary Session Communiqué, September 10, 2009.

102 See the MPHRP website: http://www.mphrp.org/about us.php.

103 CGPCS, Second Plenary Session Communiqué, March 17, 2009

104 Interview with Jon Huggins, Director, OBP, One Earth Future Foundation, March 12, 2013.

105 CGPCS, Eleventh Plenary Session Communiqué, March 29, 2012.

106 Pierre Saint Hilaire, "Somalia: Following the Paper Trail," presented at the United Arab Emirates Counter Piracy Conference: 
A Regional Response to Maritime Piracy: Enhancing Public-Private Partnerships and Strengthening Global Engagement," organized by the UAE Ministry of Foreign Affairs in partnership with global ports operator DP World, Dubai, June 2012, 4, available at: http://www.counterpiracy.ae/upload/Briefing/Pierre\%20St.\%20Hilaire-Essay-Eng-2.pdf (accessed April 19, 2013).

107 Interview with Giuseppe Maresca, Director General, Department of the Treasury, Italy, December 19, 2012.

108 "Terms of Reference Trust Fund to Support Initiatives of States Countering Piracy off the Coast of Somalia," available at: http://thecgpcs.org/trustfund.do?action=workSub1_detail (accessed April 19, 2013).

${ }_{109}$ CGPCS, Trust Fund, available at: http://thecgpcs.org/trustfund.do?action=trustFund (accessed March 29, 2013).

110 Interview with Amit Singhal, Political Affairs Officer, UNDPA, January 4, 2013.

111 Ibid.

112 Interview with James Hughes, February 22, 2013.

113 CGPCS, First Plenary Session Communiqué, January 14, 2009.

114 Interview with Shoichi Nagayoshi, Principal Deputy Director, Maritime Security Division, Ministry of Foreign Affairs, January 22, 2013.

115 Interview with James Hughes, February 22, 2013.

116 Interview with Peter Hinchliffe, January 7, 2013.

117 Interview with Thomas Winkler, December 5, 2012.

118 Interview with David Rider, President and Executive Director, Seamen's Church Institute, February $22,2013$.

119 Alan Katz, "Fighting Piracy Goes Awry with Killings of Fishermen," Bloomberg, September 17, 2012, available at: http://www. bloomberg.com/news/2012-09-16/fighting-piracy-goes-awry-with-killings-of-fishermen.html.

120 UN Security Council document S/2011/433, available at: http://www.un.org/ga/search/view doc.asp?symbol=S/2011/433.

121 CGPCS, Tenth Plenary Session Communiqué, November 17, 2011.

122 Interview with Thomas Winkler, December 5, 2012.

123 Interview with Henk Swarttouw, Ambassador of the Netherlands to Finland, March 11, 2013.

124 Interview with Henk Swarttouw, March 11, 2013.

125 Interview with Thomas Winkler, December 5, 2012 and "Massive Floating Armories with Weapons are a Pirates Dream," Guardian, January 10, 2013, available at: http://www.businessinsider.com/massive-floating-armories-filled-with-weaponsare-a-pirates-sweet-dream-2013-1.

126 “Massive Floating Armories with Weapons are a Pirates Dream," Guardian, January 10, 2013, available at: http://www. businessinsider.com/massive-floating-armories-filled-with-weapons-are-a-pirates-sweet-dream-2013-1.

127 Weiss and Thakur, Global Governance and the UN, 15

128 D. Weissbrodt and M. Kruger, "Norms on the Responsibilities of Transnational Corporations and Other Business Enterprises with Regard to Human Rights," The American Journal of International Law, Vol. 97, No. 4 (2003), pp. 901-922.

129 Data are taken from the OBP annual economic cost of piracy reports, which include attempts to systematically identify all acknowledged suspects and prosecutions of piracy. Information for piracy prosecutions in 2012 is unavailable for India, Somalia/Puntland, Somaliland, and Tanzania.

130 Interview with Donna Hopkins, November 8, 2012.

131 Interview with Thomas Winkler, December 5, 2012.

132 Interview with Donna Hopkins, November 8, 2012.

133 Interview with Henk Swarttouw, March 11, 2013.

134 Interview with Giuseppe Maresca, December 19, 2012.

135 Interview with David Rider, February 22, 2013.

136 Interview with Shoichi Nagayoshi, January 22, 2013.

137 Interview with Carl P. Salicath, December 8, 2012.

138 Saint Hilaire, "Somalia: Following the Paper Trail," 2.

139 Interview with James Hughes, February 22, 2013.

140 Interview with James Hughes, February 22, 2013.

141 Interview with Donna Hopkins, November 8, 2012.

142 CGPCS, Third Plenary Session Communiqué, May 29, 2009.

143 CGPCS, Sixth Plenary Session Communiqué, June 10, 2010. 
144 CGPCS, Fifth Plenary Session Communiqué, January 29, 2010.

145 CGPCS, Seventh Plenary Session Communiqué, November 10, 2010.

146 CGPCS, Seventh Plenary Session Communiqué, November 10, 2010.

147 Interview with Owen Doherty, Acting Associate Administrator for Business and Finance Development, US Maritime Administration, December 18, 2012.

148 Interview with James Hughes, February 22, 2013.

149 Weiss and Thakur, Global Governance and the UN, 20-22.

150 Interview with James Hughes, February 22, 2013.

151 Interview with James Hughes, February 22, 2013.

152 Interview with Henk Swarttouw, March 11, 2013.

153 Barrett, Why Cooperate? 10.

154 Interview with Thomas Winkler, December 5, 2012.

155 Interview with Owen Doherty, December 18, 2012.

156 Interview with Peter Hinchliffe, January 7, 2013.

157 Interview with Peter Hinchliffe, January 7, 2013.

158 Interview with Jon Huggins, March 12, 2013.

159 Interview with David Rider, New York, February 21, 2013.

160 GCPCS, Communiqué, New York, July 25, 2012.

161 CGPCS, Seventh Plenary Session Communiqué, November 10, 2010.

162 Interview with Thomas Winkler, December 5, 2012.

163 Interview with Peter Hinchliffe, January 7, 2013.

164 Interview with Peter Hinchliffe, January 7, 2013.

165 Interview with Donna Hopkins, November 8, 2012.

166 Email correspondence with Hayong Moon (via Jiyoung Kim), April 4, 2013.

167 Interview with Henk Swarttouw, March 11, 2013.

168 Interview with Carl P. Salicath, December 8, 2012.

169 Interview with Hester Somsen, February 13, 2013.

170 Interview with Henk Swarttouw, March 11, 2013.

171 Interview with Peter Hinchliffe, January 7, 2013.

172 Interview with Donna Hopkins, November 8, 2012.

173 UK, "Piracy Ransoms Task Force Publishes Recommendations," December 11, 2012, available at: https://www.gov.uk/ government/news/piracy-ransoms-task-force-publishes-recommendations (accessed April 6, 2013).

174 Un-attributable interview, March 2013.

175 Interview with Giuseppe Maresca, December 19, 2012.

176 David Guilfoyle, "Prosecuting Pirates: The Contact Group on Piracy off the Coast of Somalia, Governance and International Law," Global Policy 4, no. 1 (2013): 73-9.

177 Interview with Hester Somsen, February 13, 2013.

178 Email correspondence with Hayong Moon (via Jiyoung Kim), April 4, 2013.

179 UN Security Council document S/2011/433, available at: http://www.un.org/ga/search/view doc.asp?symbol=S/2011/433, available at: http://unpos.unmissions.org/LinkClick.aspx?fileticket=MLbR1KovAkA\%3d\&tabid=11461\&language=en-US

180 Interview with Hester Somsen, February 13, 2013.

181 Interview with Giuseppe Maresca, December 19, 2012.

182 Interview with James Hughes, February 22, 2013.

183 "Annex to the letter dated 6 November 2012 from the Permanent Representative of India to the United nations address to the Secretary-General," S/2012/814, November 7, 2012, available at: http://www.un.org/ga/search/view doc. asp?symbol=S/2012/814

184 Interview with Amit Singhal, January 4, 2013.

185 Emma Belcher, The Proliferation Security Initiative: Lessons for Using Nonbinding Agreements (New York: Council on Foreign Relations, 2011). 
186 Jaceck Durkaleck, "The Proliferation Security Initiative: Evolution and Future Prospects," EU Non-proliferation Consortium Non-Proliferation papers, no. 16, June 2012, available at: http://www.nonproliferation.eu/documents/ nonproliferationpapers/jacekdurkalec4fcc7fd95cfff.pdf.

187 "The Kimberley Process," available at: http://www.globalwitness.org/campaigns/conflict/conflict-diamonds/kimberleyprocess.

188 "Annex to the letter dated 6 November 2012 from the Permanent Representative of India to the United nations address to the Secretary-General," S/2012/814, November 7, 2012, available at: http://www.un.org/ga/search/view_doc. asp?symbol=S/2012/814.

189 Henk Swarttouw, "International Community's Response: The Activity of the Contact Group on Piracy off the Coast of Somalia," June 2012, available at: http://www.counterpiracy.ae/upload/Briefing/Henk\%20Swarttouw-Essay-Eng.pdf (accessed April 10, 2013. See also, Henk Swarttouw, "International Community's Response: The Activity of the Contact Group on Piracy off the Coast of Somalia," in Conference on A regional Response to Maritime Piracy, Selected Briefing Papers, ed. Theodore Karasik (Dubai: Institute for Near East and Gulf Military Analysis, 2012).

190 Interview with Henk Swarttouw, March 11, 2013.

191 Interview with Thomas Winkler, December 5, 2012. 


\section{Author Biographies}

Danielle A. Zach is senior editorial and research fellow at the Ralph Bunche Institute for International Studies of the Graduate Center of The City University of New York (CUNY), where she is engaged in issues of global governance, particularly in the area of international peace and security. She is also a member of the adjunct faculty of the Political Science Department at Adelphi University. She earned her PhD from the CUNY Graduate Center in 2013 upon completion of her dissertation on the role of diasporas in civil wars. In addition to global governance, her research interests include: conflict and violence, social movements, and migration.

D. Conor Seyle is the associate director of research and development at the One Earth Future Foundation, where he directs the foundation's research program on global governance, which emphasizes the role of private sector and other non-state actors. He is a political psychologist by training and holds a PhD in social psychology from the University of Texas at Austin.

Jens Vestergaard Madsen is the associate director for Oceans Beyond Piracy (OBP). One of his primary responsibilities is coordinating OBP's work with the CGPCS. He received a master's degree in international studies from Seoul National University, where he majored in international cooperation. His thesis explored the possibilities and limitations of replicating regional institutions, focusing on ReCAAP and the Djibouti Code of Conduct.

\section{Acknowledgements}

The authors are profoundly grateful to the following individuals for their invaluable assistance with this research endeavor: the current and past CGPCS participants who shared their knowledge and opinions through interviews, which were indispensable to the analysis; Dr. Thomas G. Weiss for reviewing an early draft of the paper; and OEF staff members Kelsey Coolidge, Jon Huggins, Kaija Hurlburt, Liza Kane-Hartnett, Carolyn Munoz, Victor Owuor, Timothy Schommer, and Roberta Spivak for art, design, critical comments, copyediting, research assistance, and reviews. 




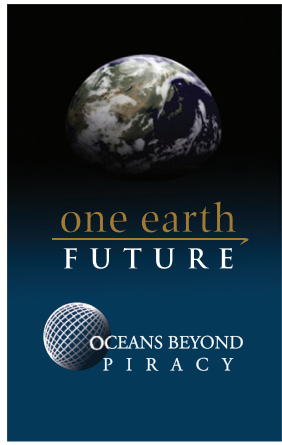

ONE EARTH FUTURE FOUNDATION

525 Zang Street $\square$ Suite $C$ Broomfield, CO 80021 USA

Ph. +1.303.533.1715 — Fax +1 303.309.0386

www.oneearthfuture.org www.oceansbeyondpiracy.org 